\title{
Randomized Control Trial on the Efficacy of Dual Bronchodilator of Glycopyrronium/Indacaterol for Lung Cancer Surgery: Improvement of Postoperative Pulmonary Function in Both Patients with Chronic Obstructive Pulmonary Disease and Normal Pulmonary Function
}

\author{
Takanori Ayabe*, Masaki Tomita, Ryo Maeda, Koichiro Ochiai, \\ Tomoka Hamahiro, Kunihide Nakamura
}

Division of Thoracic and Breast Surgery, Department of Surgery, Faculty of Medicine, University of Miyazaki, Miyazaki, Japan Email: ^tayabe@med.miyazaki-u.ac.jp

How to cite this paper: Ayabe, T., Tomita, M., Maeda, R., Ochiai, K., Hamahiro, T. and Nakamura, K. (2020) Randomized Control Trial on the Efficacy of Dual Bronchodilator of Glycopyrronium/Indacaterol for Lung Cancer Surgery: Improvement of Postoperative Pulmonary Function in Both Patients with Chronic Obstructive Pulmonary Disease and Normal Pulmonary Function. Surgical Science, 11, 133-165. https://doi.org/10.4236/ss.2020.116018

Received: May 10, 2020

Accepted: June 16, 2020

Published: June 19, 2020

Copyright ( 2020 by author(s) and Scientific Research Publishing Inc. This work is licensed under the Creative Commons Attribution International License (CC BY 4.0).

http://creativecommons.org/licenses/by/4.0/

\section{(c) (i) Open Access}

\section{Abstract}

Background: A dual bronchodilator, long-acting anticholine drugs (glycopyrronium, LAMA) and the long running $\beta_{-2}$ stimulant (indacaterol, LABA), are effective for the treatment of chronic obstructive pulmonary disease (COPD). To evaluate the effectiveness of the perioperative intervention of LAMA/LABA, a randomized prospective trial was performed for the lung cancer patients receiving a lobectomy with normal pulmonary function and COPD. Methods: Based on the results of the preoperative pulmonary function test, 25 patients were diagnosed with COPD [\% forced expiratory volume in 1 second $\left.\left(\% \mathrm{FEV}_{1}\right)<70 \%\right]$. Thirty-seven patients were enrolled as non-obstructive patients $\left(70 \% \leq \% \mathrm{FEV}_{1}\right)$, who were randomized into two groups, the LAMA/LABA $(\mathrm{n}=19)$ and the Control group $(\mathrm{n}=18)$. The LAMA/LABA and the COPD groups daily received inhaled LAMA $(50 \mu \mathrm{g})$ and LABA (110 $\mu \mathrm{g})$ for 1 week before surgery and for least 4 weeks after surgery. The Control group had no treatment of the dual bronchodilator. The actual values were measured during the perioperative pulmonary function at three points of the preoperative baseline, the postoperative 1 week and the postoperative 4 weeks; these changes and changed ratios were then calculated. The patient-reported outcomes of the quality of life (PRO-QOL) were evaluated by the Cancer Dyspnea Scale (CDS), the COPD assessment test, and the St. George's Respiratory Questionnaire. Results: Regarding the value of $\mathrm{FEV}_{1}$ at the baseline, that in the LAMA/LABA group was $79.2 \% \pm 6.4 \%$ and that in 
the Control group was $80.9 \% \pm 6.4 \%$, but that in the COPD groups was $57.9 \%$ $\pm 8.7 \%$; there was a significant difference between the COPD and the Control group ( $\mathrm{p}<0.0001$ ). At the postoperative 1 week point, the $\mathrm{FEV}_{1}$ value in the Control group was $1.3 \pm 0.5 \mathrm{~L}$ and that in the LAMA/LABA group was $1.7 \pm$ $0.5 \mathrm{~L}$. On the other hand, that in the COPD group was $1.7 \pm 0.5 \mathrm{~L}$, which was significantly higher compared to that in the Control group $(\mathrm{p}=0.0251$ and $\mathrm{p}=$ 0.0369). The intervention of LAMA/LABA for the COPD and non-obstructive patients resulted in the less decreased degree of the pulmonary function in $\mathrm{FEV}_{1}$ compared to that in the Control group. Based on the PRO-QOL by the CDS, the intervention of LAMA/LABA significantly reduced the total dyspnea in the LAMA/LABA group compared to that in the Control group ( $\mathrm{p}=$ 0.0348). Conclusion: The perioperative intervention of LAMA/LABA should lead to maintaining the postoperative pulmonary function of the $\mathrm{FEV}_{1}$ during the lobectomy with COPD and non-obstructive patients and the improvement of PRO-QOL.

\section{Keywords}

Glycopyrronium/Indacaterol, Pulmonary Function, Lobectomy, Lung Cancer, Randomized Control Trial

\section{Introduction}

Chronic obstructive pulmonary disease (COPD) continues to be a major cause of morbidity, mortality, and impaired quality of life. The prevalence of COPD was estimated to be $7.6 \%$ by a systematic review from 2006 of studies across 28 countries [1]. According to WHO estimates, 65 million people have moderate-to-very severe COPD, and it is predicted that COPD will become the third leading cause of death worldwide by 2030 [1] [2].

The impact on pulmonary function parameters is expressed by an increase in the functional residual capacity and a progressive decrease in the inspiratory reserve volume and inspiratory capacity [3]. Spirometry involves a forced expiratory manuver, which may not be the ideal test to detect subtle improvements in the airway caliber in COPD due to effort-dependent small airways closure. Furthermore, forced expiratory volume in 1 second $\left(\mathrm{FEV}_{1}\right)$ mainly measures the degree of obstruction in the large and intermediate airways [4] [5] while COPD is a disease mainly residing in the peripheral airways.

In June 2013, the Japanese Society of Respiratory published the "Guidelines for COPD Diagnosis and Treatment, 5th Edition" [6], stating that the airflow obstruction of COPD was caused by the combined action of emphysema lesions and peripheral airway lesions in various ratios. The disease types are classified in two classes, which are 1) emphysema-type COPD in which emphysema lesions predominate, and 2) non-emphysema-type COPD in which peripheral airway lesions predominate.

These various disease states are classified according to chronic bronchial in- 
flammation, exacerbation frequency, reversibility of airflow obstruction, the presence or absence and severity of shortness of breath, weight loss, respiratory failure, and pulmonary hypertension.

With the increase in lung cancer surgery in the elderly, the opportunity for surgery with COPD is increasing. The incidence of COPD in lung cancer patients is about 10\% [7], and based on the COPD epidemiological survey in Japan (between January 2000 and January 2001), 8.5\% of adults aged 40 and older ( $13.1 \%$ male, $4.4 \%$ female) have COPD [8]. In surgery, COPD is an independent risk factor for atelectasis, pneumonia, and respiratory complications, and the odds ratio of postoperative respiratory complications in patients with COPD is 1.79 (Confidence Interval, 1.44 - 2.22) [9]. COPD is an important factor that determines the postoperative complication rate and surgery-related mortality after pulmonary resection. It is recommended to take measures for postoperative respiratory complications such as respiratory physical therapy in the perioperative period for patients with COPD.

Although lung cancer should be appropriately treated according to the guidelines, lung cancer patients with COPD have a reduced pulmonary function and increased postoperative morbidity [10] [11]. The perioperative management of a patient with COPD and lung cancer, especially with preoperative rehabilitation and bronchodilators, is important for the improvement of surgical outcomes. Bronchodilators are one of the therapeutic drugs for stable COPD [12].

Long-acting bronchodilators, such as long-acting muscarinic antagonists (LAMAs) and long-acting $\beta_{2}$-agonists (LABAs), are the cornerstone of maintenance therapy for moderate-to-very severe COPD [12]. LAMAs can be combined with LABAs, resulting in enhanced bronchodilators as well as long-acting bronchodilators with a 24-hour duration of action and a once-daily dosing regimen are an merging area of clinical research and development [13] [14].

In 2008, the UPLIFT trial of long-acting anticholinergic drugs (tiotropium) in COPD patients was announced, and 6000 COPD patients in 35 countries worldwide were treated with tiotropium for 4 years to maintain improved respiratory function and quality of life mortality, and acute exacerbation rates were significantly reduced [13].

Therapy with a LAMA or a LABA is recommended as the first-line maintenance therapy for patients with moderate-to-very severe COPD [12]. These medications were primarily introduced to provide symptomatic control. Based on their efficacy in recent clinical trials versus a placebo, they are now recommended for preventing exacerbations in patients with moderate-to-severe COPD [15] [16] [17]. Current treatment guidelines [12], however, do not specify whether a LAMA or a LABA should be the preferred agent.

In a meta-analysis performed by Chong et al. in 2012 [18], a LAMA (tiotropium) reduced the number of patients experiencing one or more exacerbations when compared to the use of various LABA formulations. Since that review, larger trials comparing LAMAs with LABAs have been recently published [19] 
[20].

A few studies have shown that combinations of a LAMA and a LABA produced a significant increase in pulmonary function [21] [22]. Globally, long-acting anticholinergics (glycopyrronium, LAMA) + long-acting $\beta_{2}$-agonists (indacaterol, LABA) in patients with COPD have been treated, which were reported from the SHINE clinical trial that improved respiratory function $\left(\mathrm{FEV}_{1}\right)$ over time [21] and reports from the SPARK clinical trial that improved the quality of life (total SGRQ score) of COPD patients and suppressed COPD exacerbation [23].

Concerning the clinical perioperative management of lung cancer surgery, there is no report about a randomized clinical trial that examined the effectiveness of preserving and improving the respiratory function during the perioperative period using a combination drug of anticholinergic drugs and $\beta_{2}$-agonist. As the perioperative management of lung cancer surgical patients, we have preoperatively used a bronchodilator (tiotropium), which has shown to have an effect of improving respiratory function [24]. To administer dual bronchodilators to lung cancer patients undergoing a lobectomy to evaluate their respiratory function-improving effects, efficacy, and safety, we conducted prospective clinical studies to determine whether they can be applied to the perioperative management of thoracic surgery. We will report the obtained results and the calculated changes in the perioperative pulmonary function in both groups of the normal pulmonary function and the COPD patients and we will evaluate the detailed results by patient-reported outcomes of the quality of life (PRO-QOL).

\section{Patients and Methods}

\subsection{Study Design}

Figure 1 shows the CONSORT 2010 flowchart of patient registration. We enrolled 68 patients who would undergo a lobectomy for lung cancer.

Based on the results of preoperative spirometry, 25 patients were diagnosed with COPD [\% forced expiratory volume in 1 second $\left(\% \mathrm{FEV}_{1}\right)<70 \%$ ], of which 7 patients were excluded by the previous bronchodilator treatment history and the very high risk with severely decreased pulmonary function for surgery. Finally, 18 patients were registered for the COPD group. The COPD groups received inhaled LAMA $(50 \mu \mathrm{g})$ and LABA $(110 \mu \mathrm{g})\left(\right.$ Ultibro $^{\circledR}$ Breezhaler $^{\circledR}$, Novartis Pharma K.K., Tokyo, Japan) ( $85 \mu \mathrm{g} / 43 \mu \mathrm{g}$ inhalation powder, hard capsules, indacaterol/glycopyrronium) for 1 week before surgery and for least 4 weeks after surgery.

On the other hand, the other enrolled 43 patients showed the normal pulmonary function ( $\% \mathrm{FEV}_{1} \geq 70 \%$ ), who were diagnosed as non-obstructive patients, that is classified as having a "normal pulmonary function". Based on the exclusion criteria, 6 patients were excluded due to severe complications and past chest surgery. Finally, 37 patients were registered for the "normal pulmonary function" group. Finally, a total of 55 patients were registered for the study protocol. 


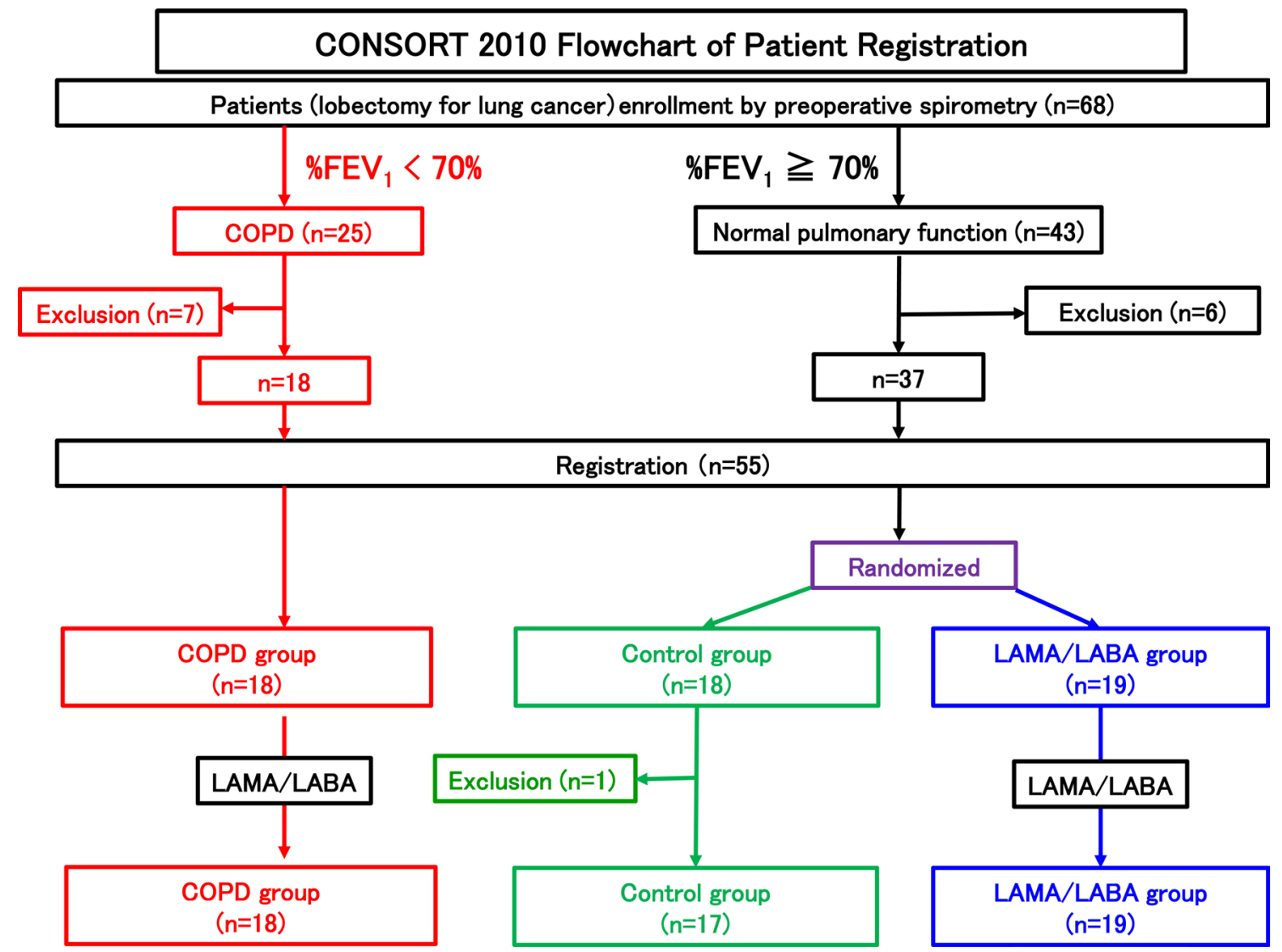

Figure 1. CONSORT 2010 flowchart of patient registration.

Furthermore, the 37 non-obstructive patients were randomized into two groups, that is, the Control group $(n=18)$ and the LAMA/LABA group $(n=19)$. The LAMA/LABA group received inhaled LAMA $(50 \mu \mathrm{g})$ and LABA $(110 \mu \mathrm{g})$ for 1 week before surgery and for least 4 weeks after surgery. As an observation group, the Control group had no treatment of the dual bronchodilator. In the Control group, 1 patient was excluded because of a defect in the implementation of the postoperative pulmonary function test. Finally, in the Control group, 17 patients were evaluated.

\subsection{Protocol Steps}

Figure 2 shows the study design and the schedule of this study. In three groups $(n=54)$, the spirometry and the patient-reported outcomes of the quality of life (PRO-QOL) were performed at three points, when it is at the preoperative baseline, the postoperative week one (1-week: $1 \mathrm{~W}$ ) after the operation, and the postoperative week four (4-weeks: $4 \mathrm{Ws}$ ) after the operation. In the LAMA/LABA group (non-obstructive patients) and the COPD group (obstructive patients), in order to evaluate the changed degree due to the preoperative intervention of the LAMA/LABA treatment, the preoperative baselines were twice measured before and after the inhalation of the LAMA/LABA treatment before surgery. 


\section{Study Design}

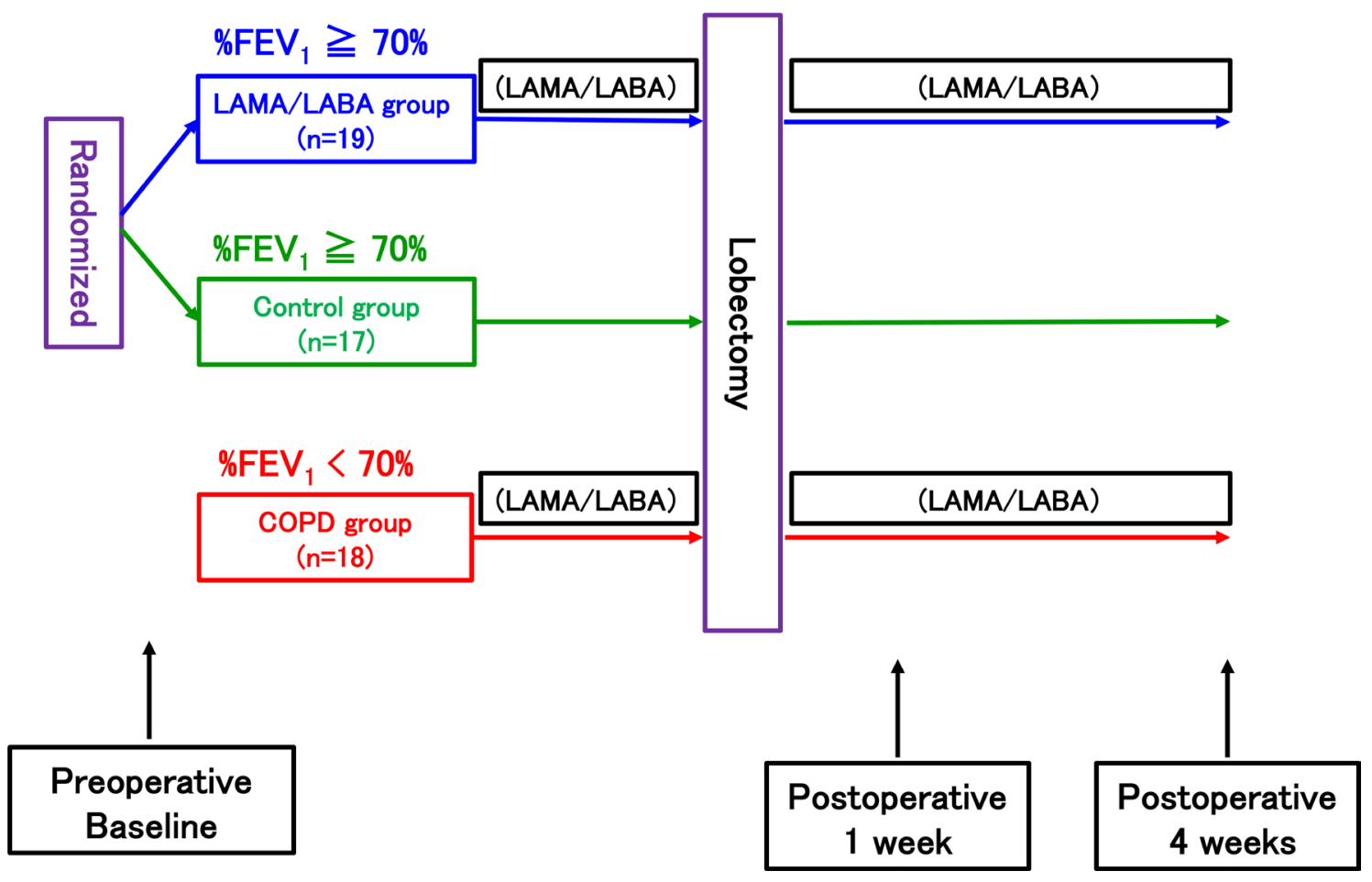

Figure 2. The treatment design and schedule of this study.

\subsection{Patients}

Patients were consulted about the surgical treatment and hospitalized at the University of Miyazaki Hospital. Those that participated in this clinical trial underwent open thoracic surgery or video-assisted thoracic surgery and received a pulmonary lobectomy for lung cancer. The study was registered as UMIN000016184 (registration date, 2015/01/12) at the University Hospital Medical Information Network Clinical Trial Registry (http://www.umin.ac.jp/ctr/) and conducted with the approval of the ethics committee of the institute. This study was approved by the University of Miyazaki Hospital Clinical Research Ethics Board (No. 2014-147) in March 2015. The registration period was between April 2015 and March 2017. All patients provided informed consent before the treatment.

\subsection{Selection Criteria}

The subjected patients were to undergo open thoracic surgery or video-assisted thoracic surgery that was performed in our department. Patients diagnosed with lung cancer, or the patients whose diagnosis had not been obtained prior to surgery, however, malignant diseases, such as lung cancer, is suspected to target patients who perform a lung resection (pulmonary lobectomy) for the purpose of biopsy (with intraoperative pathological diagnosis) and treatment (removal) for 
a chest abnormal shadow and tumor-like mass. Bronchodilators have not been given for the patients.

\subsection{Exclusion Criteria}

The patients excluded were those deemed difficult to withstand the preoperative evaluation, did not undergo the lobectomy based on preoperative diagnosis, patients who have had a past history of open thoracic surgery or previous pulmonary resection, patients who do not lead to a lobectomy due to the results of the intraoperative diagnosis, patients who have already been given bronchodilators, patients with obstructive angle glaucoma, dysuria due to enlarged prostate, urinary retention, severe decrease in serum potassium levels, and atrial fibrillation.

\subsection{Discontinuation Criteria of Treatment}

The stop criteria of treatment was when the subject offers to decline the study or withdraws their consent, if the entire study is discontinued, for any other reason such as the researcher or the attending physician determines that it is appropriate to discontinue the study, and when angle-closure glaucoma, dysuria/urinary retention due to prostatic hypertrophy, severe decrease in serum potassium level, and atrial fibrillation occur.

\subsection{Surgery}

Surgery was performed under general and epidural anesthesia with a double-lumen endobronchial tube. After establishing a single-lung ventilation, the patient was flexed in the lateral decubitus position. After a posterolateral skin incision, a thoracotomy was performed through the fifth intercostals space using the dorsalpedis muscle-sparing technique. During anatomic resection, we used an endoscopic stapler (Ethicon, Tokyo, Japan, Covidien, Tokyo, Japan) to divide the lung parenchyma and incomplete fissures, and excise the bronchi. The pulmonary arteries and veins were also divided with an endoscopic stapler if the diameter of the vessels was greater than $5 \mathrm{~mm}$. After anatomic resection and a mediastinal lymphadenectomy, we performed a water-seal test to ensure pneumostasis. Suture-lines were not buttressed, but evident pulmonary fistulae were closed with sutures and sealed with fibrin glue. A 24-French chest tube was placed in the hemithorax, and the wounds were closed. Patients were allowed to drink water 6 hours after extubation, and to eat and walk with assistance by the next morning after surgery. Patients in the LAMA/LABA group and the COPD group continued to use inhaled LAMA/LABA throughout the preoperative and postoperative periods. Patients in the Control group had no treatment of the LAMA/LABA. All patients received preoperative epidural anesthesia for pain management, which usually remained in place for 3 days, then they were started on oral analgesia from the first postoperative day, and the chest drainage tubes were removed within the discharge volume of $200 \mathrm{ml}$ per day. Postoperative spirometry was performed at the times of 1 week and 4 weeks after the surgery. 


\subsection{Assessments and Outcome Measures}

As the primary evaluation items, the actual measured parameters were obtained from the spirometry, which are performed at the point of the preoperative baseline and the "postoperative 1 week" and the "postoperative 4 weeks". The changes in the actual measured values and the changed ratios (the change, \%) were calculated between the differences before and after the surgery of the three groups.

As the secondary evaluation items, the patient-reported outcomes of the quality of life (PRO-QOL) regarding the symptom score (shortness of breath/dyspnea), that is, the Cancer Dyspnea Scale (CDS) [25] [26] [27] [28], the COPD assessment test (CAT) [29], and the St George's Respiratory Questionnaire (SGRQ) Score [30]. As the intraoperative factors, procedure, operation time, bleeding volume, blood transfusion, intrathoracic adhesion, intraoperative complications, use of staple interlobular division, complications, and use of polyglycolic acid sheet with fibrin glue for air leaks (case number) were investigated. As the postoperative factors, postoperative complications, air leak, drain detention time, adhesion therapy, postoperative therapy, hospital death over the postoperative 30-days, and survival were evaluated.

\subsection{Primary Evaluation Items of Pulmonary Function Test}

The pulmonary function test was performed using a hospital spirometer in which the vital capacity ( $\mathrm{VC})$, the predicted percentage of $\mathrm{VC}(\% \mathrm{VC}, \%$ predicted), the forced vital capacity (FVC), the forced expiratory volume in one second $\left(\mathrm{FEV}_{1}\right)$, and the percentage of $\mathrm{FEV}_{1}\left(\mathrm{FEV}_{1}\right)$ were measured on the preoperative day before the administration of the bronchodilator. The parameters of the pulmonary function tests were defined at the three points of the "preoperative baseline", the "postoperative 1 week", and the "postoperative 4 weeks".

Regarding the change in the four parameters of the $\mathrm{VC}, \% \mathrm{VC}, \mathrm{FEV}_{1}$, and $\% \mathrm{FEV}_{1}$, the transitions were calculated at two points selected from the three periods of the "preoperative baseline", the "postoperative 1 week, and the "postoperative 4 weeks". For example, in the case of " $\triangle \mathrm{VC}$ ", that is the change between the "preoperative baseline" and the "postoperative 1 week", which was represented as the " $\triangle \mathrm{VC}$ ('postoperative 1 week' - 'preoperative baseline')". This calculation equation denotes the " $\triangle \mathrm{VC}$ ('postoperative 1 week' - 'baseline')" = "the value of VC at the postoperative 1 week" - "the value of VC at the preoperative baseline"; " $\triangle \mathrm{VC}$ ('postoperative 4 weeks' - 'baseline')" = "the value of VC at the postoperative 4 weeks" - "the value of VC at the preoperative baseline"; " $\triangle \mathrm{VC}$ ('postoperative 4 weeks' - 'postoperative 1 week')" = "the value of $\mathrm{VC}$ at the postoperative 4 weeks" - "the value of $\mathrm{VC}$ at the postoperative 1 week".

As well as the parameters of the " $\triangle \mathrm{VC}$ ", for the parameters of " $\triangle \% \mathrm{VC}$ ", " $\triangle \mathrm{FEV}_{1}$ ", and " $\triangle \% \mathrm{FEV}_{1}$ ", the calculation equations are similarly represented as 
listed below; " $\triangle \% \mathrm{VC}$ ('postoperative 1 week' - 'baseline')" = "the value of $\% \mathrm{VC}$ at the postoperative 1 week" - "the value of $\% \mathrm{VC}$ at the preoperative baseline"; "\% $\triangle \mathrm{VC}$ ('postoperative 4 weeks' - 'baseline')" = "the value of $\% \mathrm{VC}$ at the postoperative 4 weeks" - "the value of \%VC at the preoperative baseline"; "\% $\triangle \mathrm{VC}$ ('postoperative 4 weeks' - 'postoperative 1 week')" = "the value of $\% \mathrm{VC}$ at the postoperative 4 weeks" - "the value of $\% \mathrm{VC}$ at the postoperative 1 week". Regarding the two parameters of " $\triangle \mathrm{FEV}_{1}$ " and " $\triangle \% \mathrm{FEV}_{1}$ ", they were also calculated between the two points from the three periods of the preoperative "baseline", the "postoperative 1 week", and the "postoperative 4 weeks".

For the changed ratios, these were represented as the calculated indicators, which were the changed percentage between the "postoperative 1 week" and the preoperative "baseline", and also that between the "postoperative 4 weeks" and the preoperative "baseline". For example, in the case of the changed ratio of VC, the following calculation equation was used: "the changed ratio of VC (\%)" = $100 \times[$ (the VC value of the "postoperative 1 week") - (the VC value of the preoperative "baseline") $] \div$ (the VC value of the preoperative "baseline")]. Regarding the cases of the changed ratio of the $\% \mathrm{VC}(\%), \mathrm{FEV}_{1}(\%)$, and $\% \mathrm{FEV}_{1}$ $(\%)$, a similar calculation equation was used, that is, "the changed ratio of the $\% \mathrm{VC}(\%), \mathrm{FEV}_{1}(\%)$, and $\% \mathrm{FEV}_{1}(\%)=100 \times[$ (the values of the 'postoperative 1 week' - the values of the 'baseline')/the values of the 'baseline'] and $100 \times$ [(the values of the 'postoperative 4 weeks' - the values of the 'baseline')/the values of the 'baseline']".

\subsection{Secondary Evaluation Items of the Patient-Reported Outcomes of Quality of Life (PRO-QOL)}

The changes in the subjective symptoms of shortness of breath and dyspnea before and after surgery were evaluated using the Cancer Dyspnea Scale (CDS) [25] [26] [27] [28], the COPD Assessment Test (CAT) questionnaire [29], and the St. George's Respiratory Questionnaire (SGRQ) total score [30].

\subsubsection{Outcomes of Cancer Dyspnea Scale.}

The Cancer Dyspnea Scale (CDS) for Assessing Dyspnea is one of the most frequent and refractory symptoms in cancer patients. The CDS was translated into English by the standard "forward-backward" translation method [25] [26] [27] by Tanaka et al. [28]; this translation produced the version of the CDS-E originally described and published in English in 2000. This instrument assesses the breathing difficulty a few days preceding its administration. It consists of 12 questions, scored on a five-point Likert scales ranging from "not at all" to "very much". The questions are grouped into three factors; i.e., sense of effort, sense of anxiety, and sense of discomfort. The original CDS used the time period of "a few days" without further definition. To operationalize this, the subjects were instructed to consider "a few days" as "within the past seven days". The CDS is a brief, valid and feasible scale for assessing the multidimensional nature of dyspnea in cancer patients. 


\subsubsection{Outcomes of the COPD Assessment Test (CAT)}

The COPD Assessment Test (CAT) [29], the type of questionnaire-description that is a patient-completed questionnaire globally assessing the impact of COPD (cough, sputum, dyspnea, chest tightness) on health status. The range of the CAT scores is from 0 - 40. Higher scores denote a more severe impact of COPD on a patient's life. The difference between stable and exacerbation patients was five units.

\subsubsection{Outcomes of St. George's Respiratory Questionnaire}

The St George's Respiratory Questionnaire (SGRQ) Score is a standardized, self-administered questionnaire for measuring impaired health and the perceived health-related-QOL in airway diseases [30]. A lower SGRQ score means better. It consists of 76 items, producing a "symptoms", an "activity", an "impact" and a "total score". The "symptoms score" assesses the patients" perception of their recent (4 weeks) respiratory problems; the "activity" score measures the patients' current disturbance to perform daily physical activity; the "impact" score evaluates the whole range of disturbances the patients currently experience in their life due to respiratory problems and the "total" score sums and weighs all the former components. The scores can range from 0 (no impairment) to 100 (the worst impairment) for each component; higher scores denote greater distress, thus a worse health-related-QOL. The questionnaire was administered and scored according to the instruction manual.

\subsection{Statistical Analysis}

The means and standard deviations are used for the description of the continuous measures. Regarding the "pathology" in Table 1 and "use of the polyglycolic acid sheet with fibrin glue for air leak" in Table 4, statistical differences between the two groups were calculated using the Chi-square $\left(\chi^{2}\right)$ test. For the preoperative baseline in the COPD group and the LAMA/LABA group, the actual measured values of the pulmonary function were statistically compared before and after the inhalation of the LAMA/LABA treatment before surgery. For the actual measured values of the pulmonary function and the PRO-QOL, those values at the three points of the preoperative "baseline", the "postoperative 1 week", and the "postoperative 4 weeks" were statistically compared between the LAMA/LABA group and the Control group, and the COPD group and the Control group. For the parameters of the changed values of pulmonary function at the "postoperative 1 week" and the "postoperative 4 weeks" from the preoperative "baseline", and for the changed ratio, these indicators were statistically compared between the LAMA/LABA group and the Control group, and the COPD group and the Control group. The data were compared, which were tested by the Student's paired t-test among each group. A p-value less than 0.05 was considered to be statistically significant. 


\section{Results}

Table 1 shows the background of the 54 registered patients (the LAMA/LABA group: $\mathrm{n}=19$, the Control group: $\mathrm{n}=17$, the COPD group: $\mathrm{n}=18$ ). The number of males was $29(29 / 54,53.7 \%)$. The average age was $71.1 \pm 10.4$ in the LAMA/LABA group, $65.2 \pm 11.2$ in the Control group, and $71.0 \pm 5.3$ in the COPD group, and there were no significant differences between the two groups. As a preoperative complication, there were COPD $(n=10)$, interstitial pneumonia $(n=3)$ and emphysema $(n=23)$ (data was not shown in Table 1$)$. All patients were diagnosed with lung cancer, the pathology was diagnosed with adenocarcinoma $(\mathrm{n}=35)$, squamous cell carcinoma $(\mathrm{n}=14)$, adenosquamous carcinoma (2), pleomorphic carcinoma (2), and small cell carcinoma (1). Regarding the "pathology", there was no significant difference between the LAMA/LAGA

Table 1. Background of patients.

\begin{tabular}{|c|c|c|c|c|c|}
\hline \multirow[b]{2}{*}{ Preoperative factors } & \multirow{2}{*}{$\begin{array}{l}\text { LAMA/LABA } \\
\text { group }(n=19)\end{array}$} & \multirow{2}{*}{$\begin{array}{l}\text { Control group } \\
\quad(\mathrm{n}=17)\end{array}$} & \multirow{2}{*}{$\begin{array}{l}\text { COPD group } \\
(\mathrm{n}=18)\end{array}$} & \multicolumn{2}{|c|}{$\mathrm{p}$ value } \\
\hline & & & & $\begin{array}{c}\text { LAMA/LABA } \\
\text { vs Control }\end{array}$ & $\begin{array}{l}\text { COPD vs } \\
\text { Control }\end{array}$ \\
\hline Gender (male/female) & $9 / 10$ & $2 / 15$ & $18 / 0$ & & \\
\hline Age (average) & $71.1 \pm 10.4$ & $65.2 \pm 11.2$ & $71.0 \pm 5.3$ & 0.0671 & 0.0731 \\
\hline \multicolumn{6}{|l|}{ Pathology } \\
\hline Adenocarcinoma & 14 & 14 & 7 & & \\
\hline Squamous cell carcinoma & 4 & & 10 & & \\
\hline Adenosquamous carcinoma & & 2 & & 0.1102 & 0.0020 \\
\hline Pleomorphic carcinoma & 1 & 1 & & & \\
\hline Small cell carcinoma & & & 1 & & \\
\hline Left/right & $9 / 10$ & $10 / 7$ & $7 / 11$ & & \\
\hline Upper/middle/middle-lower/lower lobes & $11 / 2 / 0 / 6$ & $9 / 0 / 0 / 8$ & $7 / 2 / 1 / 8$ & & \\
\hline Clinical T-factor (T1/T2/T3) & $12 / 7 / 0$ & $10 / 6 / 1$ & $7 / 9 / 2$ & & \\
\hline Clinical N-factor (N0/N1/N2) & $15 / 4 / 0$ & $15 / 1 / 1$ & $13 / 4 / 1$ & & \\
\hline Clinical M-factor (M0/M1b) & $18 / 1$ & $16 / 1$ & $18 / 0$ & & \\
\hline Clinical stage (IA/IB/IIA/IIB/IIIA/IIIB/IV) & $11 / 2 / 4 / 1 / 0 / 0 / 1$ & $10 / 3 / 1 / 1 / 1 / 0 / 1$ & $5 / 6 / 3 / 3 / 1 / 0 / 0$ & & \\
\hline Pathological T-factor (T1/T2/T3) & $12 / 7 / 0$ & $10 / 7 / 0$ & $9 / 7 / 2$ & & \\
\hline Pathological N-factor (N0/N1/N2) & $15 / 2 / 2$ & $12 / 1 / 4$ & $16 / 2 / 0$ & & \\
\hline Pathological M-factor (M0/M1b) & $18 / 1$ & $17 / 0$ & $18 / 0$ & & \\
\hline Pathological stage (IA/IB/IIA/IIB/IIIA/IIIB/IV) & $9 / 4 / 2 / 1 / 2 / 0 / 1$ & $9 / 3 / 1 / 0 / 4 / 0 / 0$ & $7 / 7 / 2 / 2 / 0 / 0 / 0$ & & \\
\hline $\mathrm{PaO}_{2}(\mathrm{mmHg})$ & $83.5 \pm 12.9$ & $71.0 \pm 11.4$ & $84.3 \pm 11.1$ & 0.1781 & 0.0370 \\
\hline $\mathrm{PaCO}_{2}(\mathrm{mmHg})$ & $39.9 \pm 3.6$ & $41.1 \pm 2.6$ & $40.5 \pm 3.1$ & 0.1781 & 0.0370 \\
\hline $\mathrm{pH}$ & $7.4 \pm 0.0$ & $7.4 \pm 0.0$ & $7.4 \pm 0.0$ & 0.1781 & 0.0370 \\
\hline Smoking history & 7 & 7 & 17 & & \\
\hline Brinkman index & $1079 \pm 613$ & $549 \pm 435$ & $1284 \pm 881$ & 0.1781 & 0.0370 \\
\hline
\end{tabular}


group and the Control group. In contrast, there was a significant difference between the Control group and the COPD group $(\mathrm{p}=0.0026)$; the squamous cell carcinoma was more significantly observed in 10 cases in the COPD group compared to that in the Control group.

The procedures were upper lobectomy $(n=27)$, middle lobectomy $(n=4)$, middle-lower lobectomy $(n=1)$, and lower lobectomy $(n=22)$. The clinical stage showed that IA:26; IB:11; IIA:8; IIB:5; IIIA:2; IIIB:0; IV:2. The pathological stage showed that IA:25; IB:14; IIA:5; IIB:3; IIIA:6; IIIB:0; IV:1.

For the analysis of the arterial blood gas, regarding the $\mathrm{PaO}_{2}$, that in the COPD group was $84.3 \pm 11.1 \mathrm{mmHg}$ which was higher than that in the Control group of $71.0 \pm 11.4 \mathrm{mmHg}$; there was a significant difference $(\mathrm{p}=0.037)$. For the $\mathrm{PaCO}_{2}$, that in the COPD group was $40.5 \pm 3.1 \mathrm{mmHg}$ which was lower than that in the Control group of $41.1 \pm 2.6 \mathrm{mmHg}$; there was a significant difference $(\mathrm{p}=0.037)$. For the smoking history, there were 31 patients $(57.4 \%, 31 / 54)$. The COPD group had a very high rate of smoking history $(94.4 \%, 17 / 18)$. For the Brinkman index, the value in the COPD group was $1284 \pm 881$, which was a significantly higher difference than that of the Control group $(549 \pm 435)(\mathrm{p}=$ 0.037).

Table 2 shows the preoperative parameters for the preoperative baseline of the pulmonary function in three groups. Between the COPD group and the Control group, the value of $\% \mathrm{FEV}_{1}$ in the COPD group $\left(\% \mathrm{FEV}_{1}<70 \%\right.$, obstructive pattern) was $57.9 \% \pm 8.7 \%$ and that in the Control group was $80.9 \% \pm 6.4 \%$; there was a significant difference $(\mathrm{p}<0.0001)$. The $\mathrm{VC}$ value was $3.5 \pm 0.8 \mathrm{~L}$ in the COPD group, which was higher than the value of $2.5 \pm 0.8 \mathrm{~L}$ in the Control group; there was significant difference $(p=0.0001)$. After the randomization of the normal pulmonary function patients $\left(\% \mathrm{FEV}_{1} \geq 70 \%\right.$, non-obstructive pattern), the values of $\% \mathrm{FEV}_{1}$ showed no significance between the LAMA/LABA group and the Control group $(79.2 \% \pm 6.4 \%$ vs $80.9 \% \pm 6.4 \%, p=0.9040)$. The background characteristics of the enrolled patients were well balanced (Table 1 and Table 2). For the values of $\% \mathrm{VC}$ and $\mathrm{FEV}_{1}$, there were no significant differences between the COPD groups and the Control group, and the LAMA/LABA group vs the Control group.

\subsection{Change in the Pulmonary Function before and after the Intervention of the Inhalation of LAMA/LABA Treatment}

Table 3(a) and Table 3(b) show the result of the effectiveness of the intervention of the LAMA/LABA treatment for the LAMA/LABA group (non-obstructive patients) and the COPD group (obstructive patients). In Table 3(a), for the values of $\mathrm{VC}, \% \mathrm{VC}, \mathrm{FEV}_{1}$, and $\% \mathrm{VC}$, these parameters before and after the inhalation of LAMA/LABA before surgery, there were no significant differences in the LAMA/LABA group. In Table 3(b), in the COPD group, for the values of $\mathrm{FEV}_{1}$, the parameters after the inhalation was $2.2 \pm 0.6 \mathrm{~L}$, although higher than that before the inhalation $(2.1 \pm 0.6 \mathrm{~L})$, however, there were no significant difference 
Table 2. The variables for the preoperative baselines.

\begin{tabular}{cccccc}
\hline \multirow{2}{*}{$\begin{array}{c}\text { Preoperative } \\
\text { baseline }\end{array}$} & $\begin{array}{c}\text { LAMA/LABA } \\
\text { group }(\mathbf{n}=19)\end{array}$ & $\begin{array}{c}\text { Control group } \\
(\mathbf{n}=17)\end{array}$ & $\begin{array}{c}\text { COPD group } \\
(\mathbf{n}=18)\end{array}$ & $\begin{array}{c}\text { LAMA/LABA } \\
\text { vs Control }\end{array}$ & $\begin{array}{c}\text { COPD vs } \\
\text { Control }\end{array}$ \\
\hline $\mathrm{VC}(\mathrm{L})$ & $2.7 \pm 0.7$ & $2.5 \pm 0.8$ & $3.5 \pm 0.8$ & 0.4066 & 0.0001 \\
$\% \mathrm{VC}(\%)$ & $99.6 \pm 20.2$ & $100.5 \pm 19.2$ & $109.1 \pm 21.5$ & 0.9909 & 0.4238 \\
$\mathrm{FEV}_{1}(\mathrm{~L})$ & $2.2 \pm 0.6$ & $2.0 \pm 0.6$ & $2.1 \pm 0.6$ & 0.5492 & 0.8888 \\
$\% \mathrm{FEV}_{1}(\%)$ & $79.2 \pm 6.4$ & $80.9 \pm 6.4$ & $57.9 \pm 8.7$ & 0.9040 & $<0.0001$ \\
\hline
\end{tabular}

Table 3. (a) Change in the values of pulmonary function before and after the intervention of inhalation of LAMA/LABA treatment in the LAMA/LABA group; (b) Change in the values of pulmonary function before and after the intervention of inhalation of LAMA/LABA treatment in the COPD group.

(a)

\begin{tabular}{cccc}
\hline \multirow{2}{*}{$\begin{array}{c}\text { LAMA/LABA } \\
\text { group }(\mathrm{n}=19)\end{array}$} & $\begin{array}{c}\text { LAMA/LABA } \\
\text { Before inhalation }\end{array}$ & $\begin{array}{c}\text { LAMA/LABA } \\
\text { After inhalation }\end{array}$ & LAMA/LABA vs Control \\
\cline { 4 - 4 } & $2.7 \pm 0.7$ & $2.7 \pm 0.7$ & 0.9372 \\
$\mathrm{VC}(\mathrm{L})$ & $99.6 \pm 20.2$ & $101.2 \pm 23.4$ & 0.8270 \\
$\% \mathrm{VC}(\%)$ & $2.2 \pm 0.6$ & $2.2 \pm 0.6$ & 0.9967 \\
$\mathrm{FEV}_{1}(\mathrm{~L})$ & $79.2 \pm 6.4$ & $80.7 \pm 5.8$ & 0.4706 \\
\hline $\mathrm{FEV}_{1}(\%)$ & &
\end{tabular}

(b)

\begin{tabular}{cccc}
\hline \multirow{2}{*}{$\begin{array}{c}\text { COPD group } \\
(\mathbf{n}=18)\end{array}$} & $\begin{array}{c}\text { LAMA/LABA } \\
\text { Before inhalation }\end{array}$ & $\begin{array}{c}\text { LAMA/LABA } \\
\text { After inhalation }\end{array}$ & p value \\
\hline $\mathrm{VC}(\mathrm{L})$ & $3.5 \pm 0.8$ & $3.7 \pm 0.8$ & COPD vs Control \\
\hline$\% \mathrm{VC}(\%)$ & $109.1 \pm 21.5$ & $114.3 \pm 20.2$ & 0.6118 \\
$\mathrm{FEV}_{1}(\mathrm{~L})$ & $2.1 \pm 0.6$ & $2.2 \pm 0.6$ & 0.4706 \\
$\% \mathrm{FEV}_{1}(\%)$ & $57.9 \pm 8.7$ & $62.7 \pm 13.2$ & 0.4191 \\
\hline
\end{tabular}

before and after the inhalation. At the baseline before surgery, there was no effective improvement in the pulmonary function by the inhalation of LAMA/LABA.

\subsection{The Intraoperative Factors}

Table 4 shows the breakdown and the variables in the intraoperative factors. In the right lobectomies, shown are the upper $(n=13)$, middle $(n=4)$, middle-lower $(n=1)$, and lower $(n=10)$. In the left lobectomies, shown are the upper $(n=14)$ and lower $(n=12)$. The performed approaches were an open thoracotomy $(n=51)$ and video-assisted thoracic surgery $(n=3)$.

For the operation time and the bleeding volume, between the LAMA/LABA group and the Control group, there were no significant differences. In contrast, between the COPD group and the Control group, for the operation time and the bleeding time, those parameters in the COPD group were significantly longer 
Table 4. The breakdown and the variables in the intraoperative factors.

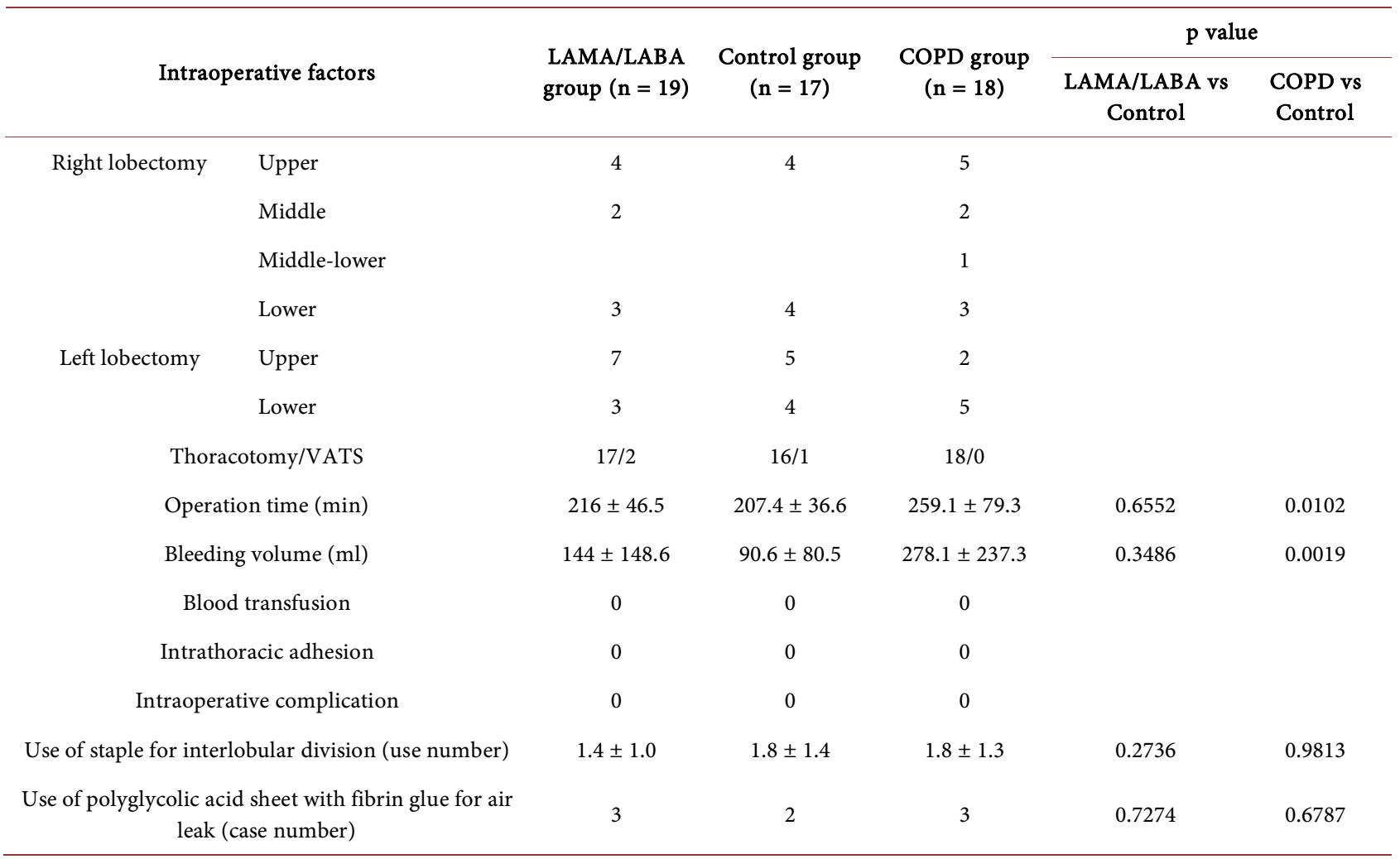

than those in the Control group $(259.1 \pm 79.3$ versus $207.4 \pm 36.6, \mathrm{p}=0.0102)$ and $(278.1 \pm 237.3$ versus $90.6 \pm 80.5, p=0.0019)$. However, there was no blood transfusion, no intrathoracic adhesion, and no intraoperative complications among the three groups.

Regarding the use of staples for the interlobular division, there were no significant differences between the LAMA/LABA group and the Control group and between the COPD group and the Control group. For the use of the polyglycolic acid sheet with fibrin glue for air leak, which was used in 8 cases $(8 / 54,14.8 \%)$, there was no significant difference between the LAMA/LABA group and the Control group and between the COPD group and the Control group.

\subsection{The Postoperative Factors}

Table 5 shows the breakdown and the variables of the postoperative factors. For the postoperative complications, they were observed in 11 cases with pneumonia (3), recurrent nerve paralysis (2), atelectasis (1), wound infection (2), subcutaneous bleeding (1), subcutaneous emphysema (1), and subcutaneous effusion (1). Air leaks were observed in 14 cases. For the drain detention period, there were no significant differences among the three groups. There was adhesion therapy in 1 case in the COPD group. For the postoperative treatment, there were 13 cases, that is, chemotherapy (8), tegafur/uracil (4), and stereotactic radiosurgery plus gefitinib (1). There were no in-hospital deaths after postoperative 30-days. 
Table 5. The breakdown and the variables in the postoperative factors.

\begin{tabular}{|c|c|c|c|c|c|}
\hline \multirow[b]{2}{*}{ Postoperative factors } & \multirow{2}{*}{$\begin{array}{c}\text { LAMA/LABA } \\
\text { group } \\
(\mathrm{n}=19)\end{array}$} & \multirow{2}{*}{$\begin{array}{l}\text { Control } \\
\text { group } \\
(n=17)\end{array}$} & \multirow{2}{*}{$\begin{array}{l}\text { COPD } \\
\text { group } \\
(n=18)\end{array}$} & \multicolumn{2}{|c|}{$\mathrm{p}$ value } \\
\hline & & & & $\begin{array}{c}\text { LAMA/LABA } \\
\text { vs Control }\end{array}$ & $\begin{array}{c}\text { COPD vs } \\
\text { Control }\end{array}$ \\
\hline \multicolumn{6}{|l|}{ Postoperative complications } \\
\hline Pneumonia & & 1 & 2 & & \\
\hline Athelectasis & & & 1 & & \\
\hline Recurrent nerve paralysis & 1 & & 1 & & \\
\hline Wound infection & & 1 & 1 & & \\
\hline Subcutaneous bleeding & 1 & & & & \\
\hline Subcutaneous emphysema & & 1 & & & \\
\hline Subcutaneous effusion & 1 & & & & \\
\hline Air leak & 7 & 3 & 4 & & \\
\hline Drain detention time (day) & $3.6 \pm 1.1$ & $4.6 \pm 2.8$ & $5.5 \pm 2.8$ & 0.2327 & 0.2611 \\
\hline Adhesion therapy & 0 & 0 & 1 & & \\
\hline \multicolumn{6}{|l|}{ Postoperative therapy } \\
\hline Chemotherapy & 2 & 3 & 3 & & \\
\hline Tegafur/Uracil (1) & 1 & 1 & 2 & & \\
\hline $\begin{array}{c}\text { Stereotactic Radiosurgery + } \\
\text { Gefitinib }\end{array}$ & 1 & & & & \\
\hline $\begin{array}{l}\text { In-hospital death after the } \\
\text { postoperative } 30 \text {-days }\end{array}$ & 0 & 0 & 0 & & \\
\hline
\end{tabular}

\subsection{Actual Measured Parameters of Pulmonary Function}

Table 6 shows the results of the measured values of the pulmonary function at the point of "postoperative 1 week" and "postoperative 4 weeks". The measured values of $\mathrm{VC}, \% \mathrm{VC}, \mathrm{FEV}_{1}$, and $\% \mathrm{FEV}_{1}$ at the point of "postoperative 1 week" and the "postoperative 4 weeks" were compared to the values based on the preoperative "baseline" variables in Table 2, and which were compared between two groups of the LAMA/LABA group and the Control group, and those of the COPD group for the Control group.

In Table 2, in the Control group, the preoperative VC value was $2.5 \pm 0.8 \mathrm{~L}$, the postoperative $\mathrm{VC}$ value decreased to $1.7 \pm 0.5 \mathrm{~L}$ at "postoperative 1 week" and $1.9 \pm 0.5 \mathrm{~L}$ at "postoperative 4 weeks". The preoperative $\mathrm{FEV}_{1}$ value of the Control group was $2.0 \pm 0.6 \mathrm{~L}$, the postoperative $\mathrm{FEV}_{1}$ value decreased to be 1.3 $\pm 0.4 \mathrm{~L}$ at "postoperative 1 week" and $1.5 \pm 0.4 \mathrm{~L}$ at "postoperative 4 weeks". The preoperative $\% \mathrm{FEV}_{1}$ value of the Control group was $80.9 \pm 6.4 \%$, the postoperative $\% \mathrm{FEV}_{1}$ value was not changed and almost the same of $79.7 \pm 9.1 \%$ at "postoperative 1 week" and $79.4 \pm 8.9 \%$ at "postoperative 4 weeks".

In contrast, in the COPD group, the preoperative $\mathrm{VC}$ value was $3.5 \pm 0.8 \mathrm{~L}$, the postoperative VC value decreased to $2.6 \pm 0.8 \mathrm{~L}$ at "postoperative 1 week" 
Table 6. The measured values of the pulmonary function at the points of the "postoperative 1 week" and the "postoperative 4 weeks".

\begin{tabular}{|c|c|c|c|c|c|}
\hline \multirow[b]{2}{*}{ Pulmonary function } & \multirow{2}{*}{$\begin{array}{c}\text { LAMA/LABA } \\
\text { group } \\
(\mathrm{n}=19)\end{array}$} & \multirow{2}{*}{$\begin{array}{l}\text { Control } \\
\text { group } \\
(n=17)\end{array}$} & \multirow{2}{*}{$\begin{array}{l}\text { COPD } \\
\text { group } \\
(n=18)\end{array}$} & \multicolumn{2}{|c|}{$\mathrm{p}$ value } \\
\hline & & & & $\begin{array}{l}\text { LAMA/LABA } \\
\text { vs Control }\end{array}$ & $\begin{array}{c}\text { COPD vs } \\
\text { Control }\end{array}$ \\
\hline \multicolumn{6}{|l|}{ Postoperative 1 week } \\
\hline $\mathrm{VC}(\mathrm{L})$ & $2.0 \pm 0.5$ & $1.7 \pm 0.5$ & $2.6 \pm 0.8$ & 0.1117 & $<0.0001$ \\
\hline$\% \mathrm{VC}(\%)$ & $74.7 \pm 15.2$ & $67.7 \pm 14.9$ & $82.2 \pm 21.9$ & 0.2340 & 0.0204 \\
\hline $\mathrm{FEV}_{1}(\mathrm{~L})$ & $1.7 \pm 0.5$ & $1.3 \pm 0.4$ & $1.7 \pm 0.5$ & 0.0251 & 0.0369 \\
\hline$\% \mathrm{FEV}_{1}(\%)$ & $82.3 \pm 6.8$ & $79.7 \pm 9.1$ & $64.2 \pm 11.6$ & 0.4045 & $<0.0001$ \\
\hline \multicolumn{6}{|l|}{ Postoperative 4 weeks } \\
\hline $\mathrm{VC}(\mathrm{L})$ & $2.1 \pm 0.6$ & $1.9 \pm 0.5$ & $2.7 \pm 0.7$ & 0.3034 & 0.0003 \\
\hline$\% \mathrm{VC}(\%)$ & $77.4 \pm 16.6$ & $76.2 \pm 13.8$ & $84.2 \pm 21.7$ & 0.8454 & 0.2067 \\
\hline $\mathrm{FEV}_{1}(\mathrm{~L})$ & $1.8 \pm 9.5$ & $1.5 \pm 0.4$ & $1.8 \pm 0.5$ & 0.1674 & 0.1438 \\
\hline$\% \mathrm{FEV}_{1}(\%)$ & $83.5 \pm 7.5$ & $79.4 \pm 8.9$ & $66.2 \pm 13.6$ & 0.2742 & 0.0007 \\
\hline
\end{tabular}

and $2.7 \pm 0.7 \mathrm{~L}$ at "postoperative 4 weeks". The preoperative of $\mathrm{FEV}_{1}$ value of the COPD group was $2.1 \pm 0.6 \mathrm{~L}$, the postoperative $\mathrm{FEV}_{1}$ values decreased to $1.7 \pm$ $0.5 \mathrm{~L}$ at "postoperative 1 week" and $1.8 \pm 0.5 \mathrm{~L}$ at "postoperative 4 weeks". However, compared to those decreased $\mathrm{FEV}_{1}$ changes in the Control group, those in the COPD group were less in degree of decrease, which were comparably maintained. The preoperative $\% \mathrm{FEV}_{1}$ value of the $\mathrm{COPD}$ group was $57.9 \% \pm$ $8.7 \%$, the postoperative $\% \mathrm{FEV}_{1}$ values rather increased to $64.2 \% \pm 11.6 \%$ at "postoperative 1 week" and $66.2 \% \pm 13.6 \%$ at "postoperative 4 weeks". Due to the inhalation of the LAMA/LABA treatment for the COPD group, the effectiveness for the $\mathrm{FEV}_{1}$ and $\% \mathrm{FEV}_{1}$ values was observed.

For the comparison of the COPD group and the Control group, for the postoperative $\mathrm{FEV}_{1}$ values, the "postoperative 1 week" $\mathrm{FEV}_{1}$ value in the Control group decreased to $1.3 \pm 0.4 \mathrm{~L}$, on the other hand, that in the COPD group was maintained at $1.7 \pm 0.5 \mathrm{~L}$; there was significant difference between the two groups $(\mathrm{p}=0.0369)$. For the "postoperative 4 weeks" $\mathrm{FEV}_{1}$ value, that in the Control group decreased to $1.5 \pm 0.4 \mathrm{~L}$ and that in the COPD group was maintained at $1.8 \pm 0.5 \mathrm{~L}$, however, there was no significant difference between the two groups ( $p=0.1438$ ). Based on these results, the postoperative $\mathrm{FEV}_{1}$ values in the COPD group were observed to be constant compared to those in the Control group.

In the LAMA/LABA group, for the preoperative parameters of $\mathrm{VC}, \% \mathrm{VC}$, $\mathrm{FEV}_{1}$, and $\% \mathrm{FEV}_{1}$, there were no significant differences between the two LAMA/LABA and Control groups. The preoperative VC value of the LAMA/LABA group was $2.7 \pm 0.7 \mathrm{~L}$, the postoperative $\mathrm{VC}$ values decreased to $2.0 \pm 0.5 \mathrm{~L}$ at "postoperative 1 week" and $2.1 \pm 0.6 \mathrm{~L}$ at "postoperative 4 weeks", and there were no significant differences between the LAMA/LABA group and the Control 
group. The preoperative $\mathrm{FEV}_{1}$ value of the LAMA/LABA group was $2.2 \pm 0.6 \mathrm{~L}$, the postoperative $\mathrm{FEV}_{1}$ values decreased to be $1.7 \pm 0.5 \mathrm{~L}$ at "postoperative 1 week" and $1.8 \pm 9.5 \mathrm{~L}$ at "postoperative 4 weeks".

For the comparison of the "postoperative 1 week" $\mathrm{FEV}_{1}$ between the LAMA/LABA group and the Control group, the values of the "postoperative 1 week" $\mathrm{FEV}_{1}$ decreased and were constant at $1.7 \pm 0.5 \mathrm{~L}$ in the LAMA/LABA group, on the other hand, in the Control group, which significantly decreased to $1.3 \pm 0.4 \mathrm{~L}$, that of the LAMA/LABA group at "postoperative 1 week" was significantly higher than that of the Control group ( $p=0.0251)$. There were no significant differences in the values of $\mathrm{VC}, \% \mathrm{VC}$, and $\% \mathrm{FEV}_{1}$ between the LAMA/LABA group and the Control group.

For the "postoperative 4 weeks" $\mathrm{FEV}_{1}$ value, that in the Control group decreased to $1.5 \pm 0.4 \mathrm{~L}$ and that in the LAMA/LABA group decreased to $1.8 \pm 9.5$ L. The value of the "postoperative 4 week" in the Control group decreased to 1.5 $\pm 0.4 \mathrm{~L}$ and that in the LAMA/LABA group was maintained at $1.8 \pm 9.5 \mathrm{~L}$, however, there was no significant difference between the two groups $(p=0.1674)$. Based on these results, the value of the postoperative $\mathrm{FEV}_{1}$ of the LAMA/LABA group was observed to be constant compared to that in the Control group.

\subsection{The Changes in the Measured Values and the Changed Ratios of The pulmonary Function}

Tables 7(a)-(e) show the results of the changed values of the measured parameters ( $\triangle \mathrm{VC}, \triangle \% \mathrm{VC}, \triangle \mathrm{FEV}_{1}$, and $\% \triangle \mathrm{FEV}_{1}$ ) and the changed ratios of the measured parameters ( $\mathrm{VC}, \% \mathrm{VC}, \mathrm{FEV}_{1}$, and $\% \mathrm{FEV}_{1}$ ).

In Table 7(a), for the changed values between the "postoperative 1 week" and the "baseline", of which the calculated values represent $\triangle \mathrm{VC}$ ("postoperative 1 week" - "baseline") (L) and $\triangle \% \mathrm{VC}$ ("postoperative 1 week" - "baseline") (L), there were no significant differences between the LAMA/LABA group and the Control group, and between the COPD group and the Control group. On the other hand, for the values of the $\triangle \mathrm{FEV}_{1}$ ("postoperative 1 week" - "baseline") (L) and the $\triangle \% \mathrm{FEV}_{1}$ ("postoperative 1 week" - "baseline") (\%), the changed value of the $\triangle \mathrm{FEV}_{1}$ ("postoperative 1 week" - "baseline") (L) in the LAMA/LABA group decreased to $-0.5 \pm 0.3 \mathrm{~L}(\mathrm{p}=0.0217)$, and that in the COPD group decreased to $-0.4 \pm 0.3 \mathrm{~L}$ ( $\mathrm{p}=0.0028)$, both which significantly decreased less compared to that of the Control group $(-0.7 \pm 0.3 \mathrm{~L})$. For the changed value of the $\triangle \% \mathrm{FEV}_{1}(\%)$ in the Control group, it decreased to $-1.2 \% \pm 7.6 \%$, and that in the COPD group rather increased to $7.1 \% \pm 7.2 \%$; thus there was a significant difference $(\mathrm{p}=0.0013)$.

In Table $7(\mathrm{~b})$, for the changed values between the "postoperative 4 weeks" and the "baseline", of which the calculated values represent $\triangle \mathrm{VC}$ ("postoperative 4 weeks" - "baseline") (L) and $\triangle \% \mathrm{VC}$ ("postoperative 4 weeks" - "baseline") (L), there were no significant differences between the LAMA/LABA group and the Control group, and between the COPD group and the Control group. 
On the other hand, for the values of the $\triangle \mathrm{FEV}_{1}$ ("postoperative 4 weeks" "baseline") (L) and the $\triangle \% \mathrm{FEV}_{1}$ ("postoperative 4 weeks" - "baseline") (\%), the changed value of the $\triangle \mathrm{FEV}_{1}$ ("postoperative 4 weeks" - "baseline") (L) in the LAMA/LABA group decreased to $-0.5 \pm 0.6 \mathrm{~L}(\mathrm{p}=0.0393)$, and that of the

Table 7. (a) Changed values between "postoperative 1 week" and "baseline"; (b) Changed values between "postoperative 4 weeks" and "baseline"; (c) Changed values between "postoperative 4 weeks" - "postoperative 1 week"; (d) Changed ratios [("postoperative 1 week" - "baseline")/“baseline”]; (e) Changed ratios [(“postoperative 4 weeks" - "baseline”)/“baseline”].

(a)

\begin{tabular}{|c|c|c|c|c|c|}
\hline \multirow{2}{*}{$\begin{array}{c}\text { Changed values between "postoperative } 1 \text { week" } \\
\text { and "baseline" }\end{array}$} & \multirow{2}{*}{$\begin{array}{l}\text { LAMA/LABA } \\
\text { group }(n=19)\end{array}$} & \multirow{2}{*}{$\begin{array}{l}\text { Control group } \\
\quad(n=17)\end{array}$} & \multirow{2}{*}{$\begin{array}{l}\text { COPD group } \\
\quad(n=18)\end{array}$} & \multicolumn{2}{|c|}{$\mathrm{p}$ value } \\
\hline & & & & $\begin{array}{l}\text { LAMA/LABA vs } \\
\text { Control }\end{array}$ & $\begin{array}{l}\text { COPD vs } \\
\text { Control }\end{array}$ \\
\hline$\triangle \mathrm{VC}$ ("postoperative 1 week" - "baseline") (L) & $-0.7 \pm 0.4$ & $-0.8 \pm 0.4$ & $-0.9 \pm 0.5$ & 0.3637 & 0.4658 \\
\hline$\Delta \% \mathrm{VC}$ ("postoperative 1 week" - "baseline") (\%) & $-24.9 \pm 12.6$ & $-32.8 \pm 12.9$ & $-27.9 \pm 16.1$ & 0.0947 & 0.3155 \\
\hline$\triangle \mathrm{FEV}_{1}$ ("postoperative 1 week" - "baseline") (L) & $-0.5 \pm 0.3$ & $-0.7 \pm 0.3$ & $-0.4 \pm 0.3$ & 0.0217 & 0.0028 \\
\hline$\Delta \% \mathrm{FEV}_{1}$ ("postoperative 1 week" - "baseline") (\%) & $3.1 \pm 6.0$ & $-1.2 \pm 7.6$ & $7.1 \pm 7.2$ & 0.0706 & 0.0013 \\
\hline
\end{tabular}

(b)

\begin{tabular}{|c|c|c|c|c|c|}
\hline \multirow{2}{*}{$\begin{array}{l}\text { Changed values between "postoperative } 4 \text { weeks" } \\
\text { and "baseline" }\end{array}$} & \multirow{2}{*}{$\begin{array}{l}\text { LAMA/LABA } \\
\text { group }(n=19)\end{array}$} & \multirow{2}{*}{$\begin{array}{l}\text { Control group } \\
\qquad(\mathrm{n}=17)\end{array}$} & \multirow{2}{*}{$\begin{array}{l}\text { COPD group } \\
\quad(n=18)\end{array}$} & \multicolumn{2}{|c|}{ p value } \\
\hline & & & & $\begin{array}{l}\text { LAMA/LABA } \\
\text { vs Control }\end{array}$ & COPD vs Control \\
\hline$\triangle \mathrm{VC}$ (“postoperative 4 weeks" - "baseline”) (L) & $-0.7 \pm 0.7$ & $-0.7 \pm 0.4$ & $-0.8 \pm 0.5$ & 0.3880 & 0.3880 \\
\hline$\triangle \% \mathrm{VC}$ ("postoperative 4 weeks" - "baseline") (\%) & $-26.2 \pm 27.9$ & $-27.2 \pm 14.8$ & $-24.9 \pm 15.6$ & 0.1511 & 0.6293 \\
\hline$\triangle \mathrm{FEV}_{1}$ (“postoperative 4 weeks" - "baseline”) (L) & $-0.5 \pm 0.6$ & $-0.6 \pm-0.4$ & $-0.3 \pm 0.3$ & 0.0393 & 0.0062 \\
\hline$\triangle \% \mathrm{FEV}_{1}$ ("postoperative 4 weeks" - "baseline") (\%) & $-0.2 \pm 20.2$ & $-1.7 \pm 10.6$ & $8.3 \pm 9.2$ & 0.0514 & 0.0018 \\
\hline
\end{tabular}

(c)

\begin{tabular}{|c|c|c|c|c|c|}
\hline \multirow{2}{*}{$\begin{array}{c}\text { Changed values between "postoperative } 4 \text { weeks" - "postoperative } \\
1 \text { week" }\end{array}$} & \multirow{2}{*}{$\begin{array}{l}\text { LAMA/LABA } \\
\text { group } \\
(n=19)\end{array}$} & \multirow{2}{*}{$\begin{array}{l}\text { Control } \\
\text { group } \\
(n=17)\end{array}$} & \multirow{2}{*}{$\begin{array}{l}\text { COPD } \\
\text { group } \\
(n=18)\end{array}$} & \multicolumn{2}{|c|}{$\mathrm{p}$ value } \\
\hline & & & & $\begin{array}{l}\text { LAMA/LABA } \\
\text { vs Control }\end{array}$ & $\begin{array}{l}\text { Control vs } \\
\text { COPD }\end{array}$ \\
\hline$\triangle \mathrm{VC}$ (“postoperative 4 weeks" - “postoperative 1 week”) (L) & $0 \pm 0.6$ & $0.2 \pm 0.1$ & $0.1 \pm 0.2$ & 0.4917 & 0.5668 \\
\hline$\triangle \% \mathrm{VC}$ ("postoperative 4 weeks" - "postoperative 1 week”) (\%) & $-1.3 \pm 22.7$ & $7.4 \pm 5.3$ & $3.8 \pm 7.0$ & 0.1261 & 0.1597 \\
\hline$\triangle \mathrm{FEV}_{1}$ ("postoperative 4 weeks" - "postoperative 1 week") (L) & $0 \pm 0.4$ & $0.2 \pm 0.1$ & $0.1 \pm 0.2$ & 0.0944 & 0.0736 \\
\hline$\triangle \% \mathrm{FEV}_{1}$ ("postoperative 4 weeks" - "postoperative 1 week”) (\%) & $-3.2 \pm 19.3$ & $0.4 \pm 7.0$ & $0 \pm 6.5$ & 0.6974 & 0.8697 \\
\hline
\end{tabular}

(d)

\begin{tabular}{|c|c|c|c|c|c|}
\hline \multirow{2}{*}{$\begin{array}{c}\text { Changed ratios [(“postoperative } 1 \text { week" - } \\
\text { "baseline")/"baseline] }\end{array}$} & \multirow[b]{2}{*}{$\begin{array}{l}\text { LAMA/LABA } \\
\text { group }(n=19)\end{array}$} & \multirow{2}{*}{$\begin{array}{l}\text { Control group } \\
\qquad(\mathrm{n}=17)\end{array}$} & \multirow{2}{*}{$\begin{array}{l}\text { COPD group } \\
\qquad(\mathrm{n}=18)\end{array}$} & \multicolumn{2}{|c|}{$\mathrm{p}$ value } \\
\hline & & & & $\begin{array}{l}\text { LAMA/LABA vs } \\
\text { Control }\end{array}$ & $\begin{array}{l}\text { Control vs } \\
\text { COPD }\end{array}$ \\
\hline Changed ratio of VC (\%) & $-0.3 \pm 0.1$ & $-0.3 \pm 0.1$ & $-0.2 \pm 0.2$ & 0.0746 & 0.0720 \\
\hline Changed ratio of $\% \mathrm{VC}(\%)$ & $-0.2 \pm 0.1$ & $-0.3 \pm 0.1$ & $-0.2 \pm 0.2$ & 0.0469 & 0.0725 \\
\hline Changed ratio of $\mathrm{FEV}_{1}(\%)$ & $-0.2 \pm 0.1$ & $-0.4 \pm 0.1$ & $-0.2 \pm 0.2$ & 0.0025 & 0.0001 \\
\hline Changed ratio of $\% \mathrm{FEV}_{1}(\%)$ & $0 \pm 0.1$ & $-0.01 \pm 0.1$ & $0.1 \pm 0.1$ & 0.1049 & 0.0002 \\
\hline
\end{tabular}


(e)

\begin{tabular}{|c|c|c|c|c|c|}
\hline \multirow{2}{*}{$\begin{array}{c}\text { Changed ratios [("postoperative } 4 \text { weeks" - } \\
\text { "baseline")/"baseline"] }\end{array}$} & \multirow{2}{*}{$\begin{array}{l}\text { LAMA/LABA } \\
\text { group }(n=19)\end{array}$} & \multirow{2}{*}{$\begin{array}{l}\text { Control group } \\
\quad(\mathrm{n}=17)\end{array}$} & \multirow{2}{*}{$\begin{array}{l}\text { COPD group } \\
\quad(n=18)\end{array}$} & \multicolumn{2}{|c|}{ p value } \\
\hline & & & & $\begin{array}{l}\text { LAMA/LABA vs } \\
\text { Control }\end{array}$ & $\begin{array}{l}\text { Control vs } \\
\text { COPD }\end{array}$ \\
\hline Changed ratio of VC (\%) & $-0.2 \pm 0.2$ & $-0.3 \pm 0.1$ & $-0.2 \pm 0.1$ & 0.2538 & 0.4800 \\
\hline Changed ratio of $\% \mathrm{VC}(\%)$ & $-0.2 \pm 0.2$ & $-0.3 \pm 0.1$ & $-0.1 \pm 0.2$ & 0.2617 & 0.4791 \\
\hline Changed ratio of $\mathrm{FEV}_{1}(\%)$ & $-0.2 \pm 0.2$ & $-0.3 \pm 0.1$ & $0.1 \pm 0.2$ & 0.0301 & 0.0015 \\
\hline Changed ratio of $\% \mathrm{FEV}_{1}(\%)$ & $0 \pm 0.3$ & $-0.02 \pm 0.1$ & $0.1 \pm 0.2$ & 0.0972 & 0.0005 \\
\hline
\end{tabular}

COPD group decreased to $-0.3 \pm 0.3 \mathrm{~L}(\mathrm{p}=0.0062)$, both which significantly decreased less compared to that of the Control group $(-0.6 \pm-0.4 \mathrm{~L})$. For the changed value of the $\triangle \% \mathrm{FEV}_{1}$ ("postoperative 4 weeks" - "baseline") (\%) in the Control group, that decreased to $-1.7 \% \pm 10.6 \%$, and that in the COPD group rather increased to $8.3 \% \pm 9.2 \%$; thus there was a significant difference $(\mathrm{p}=$ 0.0018).

In Table 7(c), for the changed degrees between the "postoperative 4 weeks" and the "postoperative 1 week", the changed degrees of $\triangle \mathrm{VC}, \triangle \% \mathrm{VC}, \triangle \mathrm{FEV}_{1}$, and $\triangle \% \mathrm{FEV}_{1}$, which were small and there were no significant differences between the groups.

In Table 7(d), for the changed ratios ("postoperative 1 week" - "baseline")/"baseline", the changed ratio of $\% \mathrm{VC}(\%)$ in the LAMA/LABA group decreased to $-0.2 \% \pm 0.1 \%$, that in the Control group decreased to $-0.3 \% \pm 0.1 \%$, and there was a significant difference, that in the LAMA/LABA was constant and decreased less than that in the Control group $(p=0.0469)$. For the changed ratios ("postoperative 1 week" - "baseline")/"baseline", the changed ratio of $\mathrm{FEV}_{1}(\%)$ in the LAMA/LABA group decreased to $-0.2 \% \pm 0.1 \%(\mathrm{p}=0.0025)$, and that in the COPD group decreased to $-0.2 \% \pm 0.2 \%(\mathrm{p}=0.0001)$, both which significantly decreased less compared to that of the Control group $(-0.4 \%$ $\pm 0.1 \%)$. For the changed ratio of $\% \mathrm{FEV}_{1}(\%)$ in the Control group, it decreased to be $-0.01 \% \pm 0.1 \%$, and that in the COPD group rather increased to be $0.1 \% \pm$ $0.1 \%$; thus there was a significant difference $(\mathrm{p}=0.0002)$.

In Table $7(\mathrm{e})$, for the changed ratios ("postoperative 4 weeks" - "baseline")/"baseline", the changed ratio of $\mathrm{FEV}_{1}(\%)$ in the LAMA/LABA group decreased to $-0.2 \% \pm 0.2 \%(\mathrm{p}=0.0301)$, and that in the COPD group decreased to $0.1 \% \pm 0.2 \%(\mathrm{p}=0.0015)$, both which significantly decreased less compared to that of the Control group $(-0.3 \% \pm 0.1 \%)$. The changed ratio of $\% \mathrm{FEV}_{1}(\%)$ in the Control group decreased to $-0.02 \% \pm 0.1 \%$, and that in the COPD group rather increased to $0.1 \% \pm 0.2 \%$; thus there was a significant difference $(\mathrm{p}=$ 0.0005).

\subsection{Patient-Reported Outcomes of Cancer Dyspnea Scale for Assessing Dyspnea}

Table 8 shows the results of the outcomes of the CDS at the point of "preoperative 
Table 8. Patient-reported outcomes of Cancer Dyspnea Scale (CDS).

\begin{tabular}{|c|c|c|c|c|c|}
\hline \multirow[b]{2}{*}{ Cancer Dyspnea Scale } & \multirow{2}{*}{$\begin{array}{c}\text { LAMA/LABA } \\
\text { group } \\
(\mathrm{n}=19)\end{array}$} & \multirow{2}{*}{$\begin{array}{l}\text { Control } \\
\text { group } \\
(n=17)\end{array}$} & \multirow[b]{2}{*}{$\begin{array}{l}\text { COPD group } \\
\quad(\mathrm{n}=18)\end{array}$} & \multicolumn{2}{|c|}{$\mathrm{p}$ value } \\
\hline & & & & $\begin{array}{c}\text { LAMA/LABA } \\
\text { vs Control }\end{array}$ & $\begin{array}{c}\text { COPD vs } \\
\text { Control }\end{array}$ \\
\hline \multicolumn{6}{|l|}{ Preoperative baseline } \\
\hline Sense of effort & $0.6 \pm 2.9$ & $0.6 \pm 1.7$ & $1.5 \pm 1.7$ & 0.9879 & 0.2159 \\
\hline Sense of anxiety & $0.9 \pm 3.0$ & $0.5 \pm 1.6$ & $1.7 \pm 2.3$ & 0.6809 & 0.1840 \\
\hline Sense of discomfort & $0.2 \pm 2.2$ & $0.2 \pm 0.6$ & $0.2 \pm 0.5$ & 0.9435 & 0.9803 \\
\hline Total dyspnea & $1.7 \pm 5.7$ & $1.3 \pm 3.3$ & $3.4 \pm 2.6$ & 0.8004 & 0.1405 \\
\hline \multicolumn{6}{|l|}{ Postoperative 1 week } \\
\hline Sense of effort & $3.0 \pm 2.1$ & $3.7 \pm 3.4$ & $5.1 \pm 3.5$ & 0.6817 & 0.2305 \\
\hline Sense of anxiety & $4.0 \pm 2.9$ & $4.1 \pm 2.6$ & $3.9 \pm 3.0$ & 0.9056 & 0.8516 \\
\hline Sense of discomfort & $0.4 \pm 0.9$ & $1.5 \pm 4.1$ & $1.7 \pm 2.9$ & 0.2970 & 0.8622 \\
\hline Total dyspnea & $7.4 \pm 4.6$ & $9.3 \pm 7.4$ & $10.7 \pm 6.8$ & 0.5451 & 0.5663 \\
\hline \multicolumn{6}{|l|}{ Postoperative 4 weeks } \\
\hline Sense of effort & $2.7 \pm 2.7$ & $5.8 \pm 2.5$ & $3.3 \pm 4.8$ & 0.0731 & 0.1485 \\
\hline Sense of anxiety & $3.9 \pm 3.4$ & $5.3 \pm 1.1$ & $4.3 \pm 5.3$ & 0.4033 & 0.5467 \\
\hline Sense of discomfort & $0.7 \pm 1.4$ & $3.2 \pm 2.9$ & $1.8 \pm 5.4$ & 0.1159 & 0.3890 \\
\hline Total dyspnea & $7.4 \pm 5.5$ & $14.3 \pm 5.2$ & $9.5 \pm 8.6$ & 0.0348 & 0.1124 \\
\hline
\end{tabular}

baseline", "postoperative 1 week" and "postoperative 4 weeks" among the three groups. The CDS is composed of three factors (sense of effort, sense of anxiety, and sense of discomfort) using a factor analysis. In the COPD group at the preoperative baseline, the parameters of the sense of effort, sense of anxiety, and total dyspnea were the highest compared to those in the LAMA/LABA and Control groups, thus there was no significant difference. Regarding the parameters of the total dyspnea compared to the status of dyspnea at the "preoperative baseline", which increased during the surgery period, as time passed, the degree of total dyspnea showed an increased status at the "postoperative 1 week" and the "postoperative 4 weeks".

For the calculated parameters of the "total dyspnea" at the "postoperative 4 weeks", that in the LAMA/LABA group increased to $7.4 \pm 5.5$ and that in the Control group increased to $14.3 \pm 5.2$. The increased parameters of the "total dyspnea" of the LAMA/LABA group at the "postoperative 4 weeks" were lower than those of the Control group, thus there was a significant difference $(\mathrm{p}=$ 0.0348). On the other hand, the parameters of the "total dyspnea" in the COPD group increased to $9.5 \pm 8.6$, which was lower than those of the Control group, thus there was no significant difference $(\mathrm{p}=0.1124)$.

In the Control group, the parameter of the "total dyspnea" at the "preoperative baseline" was the lowest among the three groups, however, this value gradually increased to $9.3 \pm 7.4$ at the "postoperative 1 week" and was $14.3 \pm 5.2$ at the 
"postoperative 4 weeks", the parameter at the "postoperative 4 weeks" in the Control group which became the highest among the three groups. In contrast, the parameters of "total dyspnea" at the "postoperative 4 weeks" in the LAMA/LABA group and the COPD group, which showed lower values compared to that of the Control group, and there was no increase during the "postoperative 1 week" and the "postoperative 4 weeks" in the LAMA/LABA group and in the COPD group. Based on the results of the lower parameters of "total dyspnea" at the point of "postoperative 4 week" in the LAMA/LABA group and in the COPD group, the intervention of the LAMA/LABA treatment for both the LAMA/LABA group and the COPD group, of which the total dyspnea symptom was observed to be maintained compared to that of the Control group.

\subsection{Patient-Reported Outcomes of COPD Assessment Test (CAT)}

Table 9 shows the results of the outcomes of the COPD assessment test (CAT) before and after surgery, which contained symptoms, activity, impacts, and total scores. For the comparison of the "total score" of the "preoperative baseline", the value of the COPD group $(9.0 \pm 6.7)$ was the highest and that of the Control group $(3.4 \pm 3.2)$ was the lowest of the three groups. The value of the COPD group of the "preoperative baseline" was higher than that of the Control group $(\mathrm{p}=0.0056)$. Compared to the measured values of the "total score" of the "preoperative baseline" with those values at the "postoperative 1 week" of the three groups, those three values of the "postoperative 1 week" increased to similar values, and there was no significant difference between the three groups. For the measured value of the "total score" of the "postoperative 4 weeks", the value of the Control group was $16.6 \pm 5.1$ was the highest of the three groups, and higher than that of the COPD group $(14.3 \pm 9.0, \mathrm{p}=0.4992)$, although the value of the Control group of the "preoperative baseline" was $3.4 \pm 3.2$, the lowest of the three groups. Although the Control group had no treatment of the LAM/LABA, the degree of the increased parameters of the "total score" became the highest between the "preoperative baseline" and the "postoperative 4 week".

\subsection{Patient-Reported Outcomes of St. George's Respiratory Questionnaire}

Table 10 shows the results of the outcomes from the St. George's Respiratory Questionnaire including 4 types of scores, that is, symptoms, activity, impacts, and total scores, which were performed at the "preoperative baseline", the "postoperative 1 week" and the "postoperative 4 weeks". For the "preoperative baseline", the "postoperative 1 week" and the "postoperative 4 weeks", the symptoms scores of the COPD group were $30.0 \pm 17.6,30.0 \pm 17.6,27.4 \pm 14.4$, significantly higher than those of the Control group $(\mathrm{p}=0.0012, \mathrm{p}=0.0010$, and $\mathrm{p}=0.0026$ ). In contrast, for the symptoms, activity, impact, total scores, at the three points of the "preoperative baseline", the "postoperative 1 week" and the "postoperative 4 weeks", there were no significant differences between the 
Table 9. Patient-reported outcomes of COPD assessment test (CAT).

\begin{tabular}{cccccc}
\hline Total score & $\begin{array}{c}\text { LAMA/LABA } \\
\text { group }\end{array}$ & $\begin{array}{c}\text { Control } \\
\text { group }\end{array}$ & $\begin{array}{c}\text { COPD group } \\
(\mathrm{n}=19)\end{array}$ & $(\mathrm{n}=17)$ & \multicolumn{2}{c}{ p value } \\
\cline { 5 - 7 } & & & $\begin{array}{c}\text { LAMA/LABA } \\
\text { vs Control }\end{array}$ & $\begin{array}{c}\text { COPD vs } \\
\text { Control }\end{array}$ \\
\hline Preoperative baseline & $5.9 \pm 5.6$ & $3.4 \pm 3.2$ & $9.0 \pm 6.7$ & 0.1824 & 0.0056 \\
Postoperative 1 week & $12.6 \pm 5.2$ & $15.6 \pm 6.7$ & $15.0 \pm 9.7$ & 0.2444 & 0.8107 \\
Postoperative 4 weeks & $11.8 \pm 7.7$ & $16.6 \pm 5.1$ & $14.3 \pm 9.0$ & 0.1655 & 0.4992 \\
\hline
\end{tabular}

Table 10. Patient-reported outcomes of St. George's Respiratory Questionnaire (SGRQ).

\begin{tabular}{cccccc}
\hline $\begin{array}{c}\text { St. George's Respiratory } \\
\text { Questionnaire }\end{array}$ & $\begin{array}{c}\text { LAMA/LABA } \\
\text { group } \\
(\mathrm{n}=19)\end{array}$ & $\begin{array}{c}\text { Control } \\
\text { group } \\
(\mathrm{n}=17)\end{array}$ & $\begin{array}{c}\text { COPD group } \\
(\mathrm{n}=18)\end{array}$ & $\begin{array}{c}\text { LAMA/LABA } \\
\text { vs Control }\end{array}$ & $\begin{array}{c}\text { COPD v } \\
\text { Control }\end{array}$ \\
\hline Preoperative baseline & & & & & \\
Symptoms score & $20.7 \pm 16.1$ & $10.9 \pm 12.3$ & $30.0 \pm 17.6$ & 0.0773 & 0.0012 \\
Activity score & $27.0 \pm 18.0$ & $27.4 \pm 33.1$ & $36.2 \pm 20.4$ & 0.9703 & 0.3386 \\
Impacts score & $17.0 \pm 13.1$ & $16.9 \pm 21.7$ & $18.9 \pm 12.0$ & 0.9960 & 0.7448 \\
Total score & $22.2 \pm 11.3$ & $15.2 \pm 19.4$ & $26.3 \pm 13.5$ & 0.2490 & 0.0617 \\
Postoperative 1 week & & & & & \\
Symptoms score & $20.7 \pm 15.6$ & $10.9 \pm 12.3$ & $30.0 \pm 17.6$ & 0.0713 & 0.0010 \\
Activity score & $49.3 \pm 25.0$ & $58.9 \pm 25.0$ & $55.6 \pm 26.1$ & 0.3025 & 0.7481 \\
Impacts score & $28.1 \pm 19.3$ & $28.7 \pm 11.8$ & $31.0 \pm 16.2$ & 0.9156 & 0.7268 \\
Total score & $32.8 \pm 16.3$ & $35.2 \pm 11.2$ & $39.2 \pm 17.7$ & 0.6626 & 0.5420 \\
Postoperative 4 weeks & & & & & \\
Symptoms score & $20.0 \pm 16.0$ & $10.9 \pm 12.3$ & $27.4 \pm 14.4$ & 0.1361 & 0.0026 \\
Activity score & $49.9 \pm 18.4$ & $57.9 \pm 13.6$ & $51.9 \pm 25.7$ & 0.3544 & 0.5071 \\
Impacts score & $27.9 \pm 3.1$ & $34.0 \pm 12.5$ & $31.3 \pm 27.4$ & 0.5316 & 0.7872 \\
Total score & $33.8 \pm 18.0$ & $37.0 \pm 8.0$ & $37.2 \pm 22.9$ & 0.7050 & 0.9883 \\
\hline
\end{tabular}

LAMA/LABA group and the Control group. For the three groups, the measured values of "total score" of "postoperative 1 week" and "postoperative 4 weeks", which were higher compared to the "total score" of the "preoperative baseline". The increased results of the "total score" showed the exacerbation of the symptoms after the surgery in the three groups.

\section{Discussion}

COPD is a common preventable disease, characterized by a persistent airflow limitation that is usually progressive and associated with an enhanced chronic inflammatory response to noxious particles or gases [12]. According to the World Health Organization, COPD is the fourth leading cause of death worldwide [1], and its burden is projected to increase in the coming decades due to the aging of the population worldwide and the continuous exposure to risk factors 
[31]. COPD exacerbation is the major contributor to deterioration of the pulmonary function, worsening of the quality of life, increases in health care costs, need for hospitalization, and risk of death [32] [33].

Cigarette smoking is the principal and most widespread cause of this disorder, although other etiologic agents have been involved [34] [35] [36]. It has been reported that about $11 \%$ of patients with COPD are non-smokers [37].

Abnormal spirometry, commonly defined by a reduction of the forced expiratory volume in one second/forced vital capacity $\left(\mathrm{FEV}_{1} / \mathrm{FVC}\right)$ ratio below either 0.70 [34] or the age-related lower limit of normal [35] [38] [39], the hallmark of the disease. The progression of COPD is signaled by a faster than normal annual decline in the $\mathrm{FEV}_{1}$ and FVC [40] [41], as well as by an abnormal increase in static lung volumes [42]. The deterioration in the pulmonary function is associated with worsening of dyspnea, increased rate and severity of exacerbation [43] [44], a progressive inability to cope with the daily activity, and eventually premature death.

In 2001, the first Global Initiative for Chronic Obstructive Pulmonary Disease [12] report provided broad recommendations for the management of COPD [45]. Bronchodilatory medication, including short-acting $\beta_{2}$-agonists (salbutamol), LAMAs (salmeterol and formoterol), short-acting muscarinic antagonists (ipratropium bromide), and salbutamol and ipratropium bromide combinations, were recognized as central to its pharmacological management [45]. These drugs were recommended for use on a regular or "as-needed" basis for symptom relief.

In 2002, the first maintenance bronchodilator became available, tiotropium, a once-daily inhaled LAMA, delivered via a single-dose capsule inhaler device [46]. Indacaterol, the first once-daily LABA, offered rapid and sustained bronchodilation and significantly improved the pulmonary function compared to the first-generation twice-daily LABAs, formoterol and salmeterol, and tiotropium [47] [48] [49], with an acceptable safety profile with minimal cardiac effects [50] [51].

Studies have suggested that $\beta_{2}$-agonists and muscarinic antagonists may act synergistically to elicit additive effects on the pulmonary function, and provide a rationale for combining the two agents for optimized bronchodilation [52] [53]. This led to studies of the free combinations of long-acting bronchodilators that indicated significant improvements in pulmonary function and patient-reported outcomes, and a comparable safety and tolerability profile versus monotherapy in patients with moderate-to-severe COPD [54] [55] [56] [57].

LAMAs and LABAs achieve bronchodilation through different mechanisms; muscarinic antagonists block acetylcholine-mediated bronchoconstriction by binding to $M_{3}$ receptors in the airway smooth muscle [58], whereas $\beta_{2}$ agonists induce smooth muscle relaxation by stimulating the $\beta_{2}$-adrenergic receptors [53] [59]. These distinct mechanisms result in differences of the observed efficacy between the two classes of bronchodilators. Hence, some data suggest that LABAs are more effective at improving the symptoms and Health-related Quality of 
Life (HR-QoL) than LAMAs, while LAMAs are superior to LABAs in reducing exacerbations with the differential efficacy likely occurring through modes of action beyond bronchodilation [20] [53] [60] [61] [62]. Such differences provide the opportunity of combining LABAs and LAMAs in an attempt to improve the treatment outcomes.

Different combinations of a LAMA and a LABA in a single inhaler are gaining popularity for the treatment of COPD [63] [64] [65]. Due to their promising pharmacological efficiency [66] and safety [67], LABA/LAMA fixed-dose combination therapies, also known as double bronchodilation [68], are increasingly considered as a viable therapeutic option for patients with COPD.

Indacaterol/glycopyrronium (IND/GLY), an inhaled, once-daily dual bronchodilator containing the LABA indacaterol (110 $\mu \mathrm{g}$ as maleate salt) and the LAMA glycopyrronium ( $50 \mu \mathrm{g}$ as bromide salt), is indicated for maintenance therapy for COPD [69] [70]. Development of IND/GLY was driven by the need to improve the standard of care for patients with this disease in terms of symptom control and exacerbation frequency. IGNITE, an adaptive, comprehensive, and innovative Phase 3 development program, demonstrated the efficacy of IND/GLY in optimizing bronchodilation, reducing symptoms, and reducing exacerbations in patients with COPD [71]. IGNITE challenged contemporary thinking about the pharmacological treatment and management of patients with this disease.

In the meta-analysis of 23 randomized controlled trials involving 20,185 patients with stable moderate-to-very severe COPD [72], Rodrigo, G.J. et al. [72] compared the efficacy and safety of dual bronchodilation with four approved LABA/LAMA fixed-dose combinations (Indacaterol/Glycopyrronium, Umeclidinium/Vilanterol, Aclidinium/Formoterol and Tiotropium/Olodaterol) with treatment using LAMA or LABA/inhaled corticosteroid. They have shown that the LABA/LAMA combinations provided a superior efficacy and comparable safety profiles compared with either the LAMA or LABA/inhaled corticosteroid treatment. For the mild COPD patients, a short-acting bronchodilator is used when needed, such as during exercise or heavy exertion, to reduce symptoms. For the moderate COPD patients, improvement of QOL and exercise tolerance are important treatment goals in addition to symptom reduction, and long-acting bronchodilators should be regularly used when the effect low with a single agent, the combination of multiple agents are considered. For the severe COPD patients, the combination of multiple long-acting bronchodilators is used for treatment.

COPD causes impaired pulmonary function as a symptom of occlusive disorder and is associated with a significantly high incidence of postoperative pulmonary complications, such as pneumonia, acute bronchitis, and atelectasis [73]. As a preoperative management using inhalation therapy for pulmonary complications in lung cancer patients with COPD, the use of LAMA and LABA bronchodilators and smoking cessation can reduce the frequency of postopera- 
tive pulmonary complications after surgical lung resection [73] and their inhalation might be useful for not only perioperative care, but also for the long-term survival of COPD patients after surgery.

Based on our randomized clinical trial for thoracic surgical patients with lung cancer and normal pulmonary function and COPD, the use of a dual bronchodilator (glycopyrronium and indacaterol, LAMA + LABA) contributes to the perioperative management of the lung cancer patients with a low pulmonary function with COPD, the intervention of which shows better postoperative respiratory function improvement and preserving PRO-QOL. For the examination whether the use of a LABA with LAMA could optimize the preoperative pulmonary function and reduce the risk for postoperative pulmonary complications [74], preoperative LAMA/LABA therapy was associated with greater improvements in the preoperative pulmonary function and less postoperative pneumonia than LAMA therapy. These results may lead to greater improvements in the $\mathrm{FEV}_{1}$ and less postoperative pneumonia by encouraging preoperative LAMA/LABA therapy [74].

Measurements of the pulmonary function by spirometry, particularly the forced expiratory volume in one second $\left(\mathrm{FEV}_{1}\right)$, is routinely used as an indicator of efficacy in the evaluation of the bronchodilator [75]. However, COPD is a complex disease with multiple symptoms, not all of which can be determined by spirometry [76]. As such, the exclusive use of $\mathrm{FEV}_{1}$ as the primary efficacy endpoint has increasingly become questioned, as it may underestimate the true clinical benefit of the intervention [77] [78]. For healthcare professionals, evaluation of patient-reported outcomes (PRO) is of more relevance than isolated pulmonary function data, as these represent the impact of treatment from the patient's perspective [79]. The use of PRO, such as health status measurement as co-primary endpoints in COPD trials, is now recommended in the COPD guidelines [80].

For the health-related quality of life (HRQoL), the St George's Respiratory Questionnaire (SGRQ) was developed, validated, and widely used in clinical trials to assess the HRQoL [81] [82]. However, the SGRQ failed to penetrate routine clinical practice. Other PROs reported in a number of clinical studies assessed "daily symptoms", "nocturnal awaking", ability to cope with daily activities, and use of rescue medications by means of "diary cards" self-administered by patients. However, the SGRQ remains the standard for subjective health status assessment in clinical studies.

The outcome measures were the Transition Dyspnea Index (TDI) and SGRQ scores, COPD exacerbation frequency and rescue medication use. The relationships between changes in the trough forced expiratory volume in one second $\left(\triangle \mathrm{FEV}_{1}\right)$ and outcomes following treatment were assessed. They suggested that $\mathrm{FEV}_{1}$ improvements post-bronchodilation correlate with the PRO improvements. These data suggested that $\mathrm{FEV}_{1}$ improvements post-bronchodilation correlate with the PRO improvements. Further improvements in patient out- 
comes may be expected by maximizing the pulmonary function improvements.

Regarding the limitation of this study, this research was a randomized control trial study for surgical patients with normal pulmonary function, and a prospective study as a comparison of surgical patients with both COPD and normal pulmonary function. Our data were based on a single institute and a very limited low number of patients. There was significant effectiveness in preserving the postoperative pulmonary function as shown in the changed $\mathrm{FEV}_{1}$ value. Although we evaluated the surgical patient's quality of life in the perioperative term by three different types of PRO-QOLs, however, there were only significant differences in the total dyspnea by the CDS, which showed the effectiveness of improvement of the symptom, that is, the reduction of the total dyspnea in the LAMA/LABA group compared to the Control group. On the other hand, for the other indicators of PRO-QOL, there were no significant differences in the three groups. These finding should explain that the effects of surgical thoracotomy with postoperative chest pain became too significant to contradict the small changes in the symptom indicator of the PRO-QOL indicators. Actually, the open thoracotomy has a very high invasive injury compared to the minimally invasive video-assisted thoracic surgery, both of which influence much more the patients' daily life in the hospital to moderate to severe degrees of the symptom in the postoperative term, such as wound pain due to the thoracotomy, postoperative cough and sputum after the lobectomy. These postoperative symptoms become significant for preoperative daily life and are obscured by the overlap of the preoperative COPD symptoms with additional invasion of the lobectomy for lung cancer surgery. There was a low impact by the intervention of the LAMA/LABA therapy to improve the postoperative respiratory symptoms and complications.

Regarding future prospects, to increase the registered number of cases, we would like to conduct multi-institutional joint research. In addition, we would like to investigate the effect of dual bronchodilators on the postoperative respiratory function depending on the difference in the surgical procedures, such as in the upper and lower lobectomies.

\section{Conclusion}

The present study shows that the perioperative intervention of LAMA/LABA therapy for lung cancer surgery was associated with improvement of the postoperative pulmonary function in both the patients with COPD and normal pulmonary function. The results led to the improvement of the postoperative parameters of the $\mathrm{FEV}_{1}$, the preserving of the postoperative pulmonary function and the better PRO-QOL, which should contribute to improving the surgical outcome such as reducing the postoperative respiratory complications.

\section{Acknowledgements}

This study was supported by a Grant-in-Aid for Clinical Research from the 
Miyazaki University Hospital.

\section{Conflicts of Interest}

The authors declare no conflicts of interest regarding the publication of this paper.

\section{References}

[1] Halbert, R.J., Natoli, J.L., Gano, A., Badamgarav, E., Buist, A.S. and Mannino, D.M. (2006) Global Burden of COPD: Systematic Review and Meta-Analysis. European Respiratory Journal, 28, 523-532. https://doi.org/10.1183/09031936.06.00124605

[2] World Health Organization (2014) Burden of COPD. World Health Organization, Geneva.

[3] Tantucci, C., Donati, P., Nicosia, F., Bertella, E., Redolfi, S., De Vecchi, M., Corda, L., Grassi, V. and Zulli, R. (2008) Inspiratory Capacity Predicts Mortality in Patients with Chronic Obstructive Pulmonary Disease. Respiratory Medicine, 102, 613-619. https://doi.org/10.1016/j.rmed.2007.11.004

[4] Hogg, J.C., Chu, F., Utokaparch, S., Woods, R., Elliott, W.M., Buzatu, L., Cherniack, R.M., Rogers, R.M., Sciurba, F.C., Coxson, H.O. and Paré, P.D. (2004) The Nature of Small-Airway Obstruction in Chronic Obstructive Pulmonary Disease. The New England Journal of Medicine, 350, 2645-2653.

https://doi.org/10.1056/NEJMoa032158

[5] Eriksson, G., Jarenbäck, L., Peterson, S., Ankerst, J., Bjermer, L. and Tufvesson, E. (2015) A New Approach to Assess COPD by Identifying Lung Function Break-Points. International Journal of Chronic Obstructive Pulmonary Disease, 10, 2193-2202. https://doi.org/10.2147/COPD.S86059

[6] The Japanese Respiratory Society (JRS) (2018) The JRS Guidelines for the Management of Chronic Obstructive Pulmonary Disease. 5th Edition. https://www.jrs.or.jp/

[7] Sekine, Y., Iwata, T., Chiyo, M., Yasufuku, K., Motohashi, S., Yoshida, S., Suzuki, M., Iizasa, T., Saitoh, Y. and Fujisawa, T. (2003) Minimal Alteration of Pulmonary Function after Lobectomy in Lung Cancer Patients with Chronic Obstructive Pulmonary Disease. The Annals of Thoracic Surgery, 76, 356-361; Discussion 362. https://doi.org/10.1016/S0003-4975(03)00489-2

[8] Fukuchi, Y., Nishimura, M., Ichinose, M., Adachi, M., Nagai, A., Kuriyama, T., Takahashi, K., Nishimura, K., Ishioka, S., Aizawa, H. and Zaher, C. (2004) COPD in Japan: The Nippon COPD Epidemiology Study. Respirology, 9, 458-465. https://doi.org/10.1111/j.1440-1843.2004.00637.x

[9] Smetana, G.W., Lawrence, V.A. and Cornell, J.E. (2006) American College of Physicians: Preoperative Pulmonary Risk Stratification for Noncardiothoracic Surgery: Systematic Review for the American College of Physicians. Annals of Internal Medicine, 144, 581-595. https://doi.org/10.7326/0003-4819-144-8-200604180-00009

[10] Win, T., Jackson, A., Sharples, L., Groves, A.M., Wells, F.C., Ritchie, A.J. and Laroche, C.M. (2005) Relationship between Pulmonary Function and Lung Cancer Surgical Outcome. European Respiratory Journal, 25, 594-599. https://doi.org/10.1183/09031936.05.00077504

[11] Sekine, Y., Kesler, K.A., Behnia, M., Brooks-Brunn, J., Sekine, E. and Brown, J.W. (2001) COPD May Increase the Incidence of Refractory Supraventricular Arrhythmias Following Pulmonary Resection for Non-Small Cell Lung Cancer. Chest, 120, 1783-1790. https://doi.org/10.1378/chest.120.6.1783 
[12] GOLD: Global Initiative for Chronic Obstructive Lung Disease (GOLD) (2016) Global Strategy for Diagnosis, Management and Prevention of COPD. http://www.goldcopd.org/

[13] Fuso, L., Mores, N., Valente, S., Malerba, M. and Montuschi, P. (2013) Long-Acting Beta-Agonists and Their Association with Inhaled Corticosteroids in COPD. Current Medicinal Chemistry, 20, 1477-1495. https://doi.org/10.2174/0929867311320120003

[14] Malerba, M., Morjaria, J.B. and Radaeli, A. (2014) Differential Pharmacology and Clinical Utility of Emerging Combination Treatments in the Management of COPD_Role of Umeclidinium/Vilanterol. International Journal of Chronic $\mathrm{Ob}$ structive Pulmonary Disease, 9, 687-695. https://doi.org/10.2147/COPD.S47792

[15] Tashkin, D.P., Celli, B., Senn, S., Burkhart, D., Kesten, S., Menjoge, S. and Decramer, M. (2008) UPLIFT Study Investigators. A 4-Year Trial of Tiotropium in Chronic Obstructive Pulmonary Disease. The New England Journal of Medicine, 359, 1543-1554. https://doi.org/10.1056/NEJMoa0805800

[16] Calverley, P.M., Anderson, J.A., Celli, B., Ferguson, G.T., Jenkins, C., Jones, P.W., Yates, J.C. and Vestbo, J. (2007) TORCH Investigators. Salmeterol and Fluticasone Propionate and Survival in Chronic Obstructive Pulmonary Disease. The New England Journal of Medicine, 356, 775-789. https://doi.org/10.1056/NEJMoa063070

[17] Criner, G.J., Bourbeau, J., Diekemper, R.L., Ouellette, D.R., Goodridge, D., Hernandez, P., Curren, K., Balter, M.S., Bhutani, M., Camp, P.G., Celli, B.R., Dechman, G., Dransfield, M.T., Fiel, S.B., Foreman, M.G., Hanania, N.A., Ireland, B.K., Marchetti, N., Marciniuk, D.D., Mularski, R.A., Ornelas, J., Road, J.D. and Stickland, M.K. (2015) Prevention of Acute Exacerbations of COPD: American College of Chest Physicians and Canadian Thoracic Society Guideline. Chest, 147, 894-942. https://doi.org/10.1378/chest.14-1676

[18] Chong, J., Karner, C. and Poole, P. (2012) Tiotropium versus Long-Acting Beta-Agonists for Stable Chronic Obstructive Pulmonary Disease. Cochrane Database of Systematic Review, No. 9, CD009157. https://doi.org/10.1002/14651858.CD009157.pub2

[19] Wedzicha, J.A., Calverley, P.M., Seemungal, T.A., Hagan, G., Ansari, Z. and Stockley, R.A. (2008) INSPIRE Investigators. The Prevention of Chronic Obstructive Pulmonary Disease Exacerbations by Salmeterol/Fluticasone Propionate or Tiotropium Bromide. American Journal of Respiratory and Critical Care Medicine, 177, 19-26. https://doi.org/10.1164/rccm.200707-973OC

[20] Decramer, M.L., Chapman, K.R., Dahl, R., Frith, P., Devouassoux, G., Fritscher, C., Cameron, R., Shoaib, M., Lawrence, D., Young, D. and McBryan, D. (2013) INVIGORATE Investigators. Once-Daily Indacaterol versus Tiotropium for Patients with Severe Chronic Obstructive Pulmonary Disease (INVIGORATE): A Randomised, Blinded, Parallel-Group Study. The Lancet Respiratory Medicine, 1, 524-533. https://doi.org/10.1016/S2213-2600(13)70158-9

[21] Bateman, E.D., Ferguson, G.T., Barnes, N., Gallagher, N., Green, Y., Henley, M. and Banerji, D. (2013) Dual Bronchodilation with QVA149 versus Single Bronchodilator Therapy: The SHINE Study. European Respiratory Journal, 42, 1484-1494. https://doi.org/10.1183/09031936.00200212

[22] Donohue, J.F., Maleki-Yazdi, M.R., Kilbride, S., Mehta, R., Kalberg, C. and Church, A. (2013) Efficacy and Safety of Once-Daily Umeclidinium/Vilanterol 62.5/25 mcg in COPD. Respiratory Medicine, 107, 1538-1546.

https://doi.org/10.1016/j.rmed.2013.06.001 
[23] Wedzicha, J.A., Decramer, M., Ficker, J.H., Niewoehner, D.E., Sandström, T., Taylor, A.F., D'Andrea, P., Arrasate, C., Chen, H. and Banerji, D. (2013) Analysis of Chronic Obstructive Pulmonary Disease Exacerbations with the Dual Bronchodilator QVA149 Compared with Glycopyrronium and Tiotropium (SPARK): A Randomised, Double-Blind, Parallel-Group Study. The Lancet Respiratory Medicine, 1, 199-209. https://doi.org/10.1016/S2213-2600(13)70052-3

[24] Ayabe, T., Tomita, M., Chosa, E., Kawagoe, K. and Nakamura, K. (2014) Effect of Inhaled Tiotropium as a Perioperative Management of Patients Undergoing Pulmonary Resection for Primary Lung Cancer. Journal of Cancer Therapy, 5, 845-859. https://doi.org/10.4236/jct.2014.59093

[25] Bonomi, A.E., Cella, D.F., Hahn, E.A., Bjordal, K., Sperner-Unterweger, B., Gangeri, L., Bergman, B., Willems-Groot, J., Hanquet, P. and Zittoun, R. (1996) Multilingual Translation of the Functional Assessment of Cancer Therapy (FACT) Quality of Life Measurement System. Quality of Life Research, 5, 309-320. https://doi.org/10.1007/BF00433915

[26] Maneesriwongul, W. and Dixon, J.K. (2004) Instrument Translation Process: A Methods Review. Journal of Advanced Nursing, 48, 175-186. https://doi.org/10.1111/j.1365-2648.2004.03185.x

[27] White, M. and Elander, G. (1992) Translation of an Instrument. The US-Nordic Family Dynamics Nursing Research Project. Scandinavian Journal of Caring Sciences, 6, 161-164. https://doi.org/10.1111/j.1471-6712.1992.tb00145.x

[28] Tanaka, K., Akechi, T., Okuyama, T., Nishiwaki, Y. and Uchitomi, Y. (2000) Development and Validation of the Cancer Dyspnoea Scale: A Multidimensional, Brief, Self-Rating Scale. British Journal of Cancer, 82, 800-805. https://doi.org/10.1054/bjoc.1999.1002

[29] Jones, P.W, Harding, G., Berry, P., Wiklund, I., Chen, W.H. and Kline Leidy, N. (2009) Development and First Validation of the COPD Assessment Test. European Respiratory Journal, 34, 648-654. https://doi.org/10.1183/09031936.00102509

[30] Jones, P.W., Quirk, F.H., Baveystock, C.M. and Littlejohns, P. (1992) A Self-Complete Measure of Health Status for Chronic Airflow Limitation. The American Review of Respiratory Disease, 145, 1321-1327. https://doi.org/10.1164/ajrccm/145.6.1321

[31] Halbert, R.J., Isonaka, S., George, D. and Iqbal, A. (2003) Interpreting COPD Prevalence Estimates: What Is the True Burden of Disease? Chest, 123, 1684-1692. https://doi.org/10.1378/chest.123.5.1684

[32] Celli, B.R. and Barnes, P.J. (2007) Exacerbations of Chronic Obstructive Pulmonary Disease. European Respiratory Journal, 29, 1224-1238. https://doi.org/10.1183/09031936.00109906

[33] Soler-Cataluña, J.J., Martínez-García, M.A., Román Sánchez, P., Salcedo, E., Navarro, M. and Ochando, R. (2005) Severe Acute Exacerbations and Mortality in Patients with Chronic Obstructive Pulmonary Disease. Thorax, 60, 925-931. https://doi.org/10.1136/thx.2005.040527

[34] Vestbo, J., Hurd, S.S., Agustí, A.G., Jones, P.W., Vogelmeier, C., Anzueto, A., Barnes, P.J., Fabbri, L.M., Martinez, F.J., Nishimura, M., Stockley, R.A., Sin, D.D. and Rodriguez-Roisin, R. (2013) Global Strategy for the Diagnosis, Management, and Prevention of Chronic Obstructive Pulmonary Disease: GOLD Executive Summary. American Journal of Respiratory and Critical Care Medicine, 187, 347-365. https://doi.org/10.1164/rccm.201204-0596PP

[35] Siafakas, N.M., Vermeire, P., Pride, N.B., Paoletti, P., Gibson, J., Howard, P., Yernault, J.C., Decramer, M., Higenbottam, T., Postma, D.S., et al. (1995) Optimal As- 
sessment and Management of Chronic Obstructive Pulmonary Disease (COPD). The European Respiratory Society Task Force. European Respiratory Journal, 8, 1398-1420. https://doi.org/10.1183/09031936.95.08081398

[36] Bettoncelli, G., Blasi, F., Brusasco, V., Centanni, S., Corrado, A., De Benedetto, F., De Michele, F., Di Maria, G.U., Donner, C.F., Falcone, F., Mereu, C., Nardini, S., Pasqua, F., Polverino, M., Rossi, A. and Sanguinetti, C.M. (2014) The Clinical and Integrated Management of COPD. An Official Document of AIMAR (Interdisciplinary Association for Research in Lung Disease), AIPO (Italian Association of Hospital Pulmonologists), SIMER (Italian Society of Respiratory Medicine), SIMG (Italian Society of General Medicine). Multidisciplinary Respiratory Medicine, 9, Article No. 25. https://doi.org/10.1186/2049-6958-9-25

[37] Buist, A.S., McBurnie, M.A., Vollmer, W.M., Gillespie, S., Burney, P., Mannino, D.M., Menezes, A.M., Sullivan, S.D., Lee, T.A., Weiss, K.B., Jensen, R.L., Marks, G.B., Gulsvik, A. and Nizankowska-Mogilnicka, E. (2007) BOLD Collaborative Research Group. International Variation in the Prevalence of COPD (the BOLD Study): A Population-Based Prevalence Study. The Lancet, 370, 741-750. https://doi.org/10.1016/S0140-6736(07)61377-4

[38] Bettoncelli, G., Blasi, F., Brusasco, V., Centanni, S., Corrado, A., De Benedetto, F., De Michele, F., Di Maria, G.U., Donner, C.F., Falcone, F., Mereu, C., Nardini, S., Pasqua, F., Polverino, M., Rossi, A. and Sanguinetti, C.M. (2014) The Clinical and Integrated Management of COPD. Sarcoidosis Vasculitis and Diffuse Lung Disease, 31, 3-21.

[39] Pellegrino, R., Viegi, G., Brusasco, V., Crapo, R.O., Burgos, F., Casaburi, R., Coates, A., van der Grinten, C.P., Gustafsson, P., Hankinson, J., Jensen, R., Johnson, D.C., MacIntyre, N., McKay, R., Miller, M.R., Navajas, D., Pedersen, O.F. and Wanger, J. (2005) Interpretative Strategies for Lung Function Tests. European Respiratory Journal, 26, 948-968. https://doi.org/10.1183/09031936.05.00035205

[40] Tantucci, C. and Modina, D., Lung Function Decline in COPD (2012) Lung Function Decline in COPD. International Journal of Chronic Obstructive Pulmonary Disease, 7, 95-99. https://doi.org/10.2147/COPD.S27480

[41] Miller, A. and Raskin, J.M. (2014) The Natural History of COPD: Confirming and Going beyond Fletcher and Peto. European Respiratory Journal, 44, 280-283. https://doi.org/10.1183/09031936.00079514

[42] Macklem, P.T. (2010) Therapeutic Implications of the Pathophysiology of COPD. European Respiratory Journal, 35, 676-680. https://doi.org/10.1183/09031936.00120609

[43] Hurst, J.R., Vestbo, J., Anzueto, A., Locantore, N., Müllerova, H., Tal-Singer, R., Miller, B., Lomas, D.A., Agusti, A., Macnee, W., Calverley, P., Rennard, S., Wouters, E.F. and Wedzicha, J.A., Evaluation of COPD Longitudinally to Identify Predictive Surrogate Endpoints (ECLIPSE) Investigators (2010) Susceptibility to Exacerbation in Chronic Obstructive Pulmonary Disease. The New England Journal of Medicine, 363, 1128-1138. https://doi.org/10.1056/NEJMoa0909883

[44] Han, M.K., Kazerooni, E.A., Lynch, D.A., Liu, L.X., Murray, S., Curtis, J.L., Criner, G.J., Kim, V., Bowler, R.P., Hanania, N.A., Anzueto, A.R., Make, B.J., Hokanson, J.E., Crapo, J.D., Silverman, E.K., Martinez, F.J. and Washko, G.R. (2011) Chronic Obstructive Pulmonary Disease Exacerbations in the COPDGene Study: Associated Radiologic Phenotypes. Radiology, 261, 274-282.

https://doi.org/10.1148/radiol.11110173

[45] Pauwels, R.A., Buist, A.S., Calverley, P.M., Jenkins, C.R. and Hurd, S.S., GOLD Scientific Committee (2001) Global Strategy for the Diagnosis, Management, and 
Prevention of Chronic Obstructive Pulmonary Disease. NHLBI/WHO Global Initiative for Chronic Obstructive Lung Disease (GOLD) Workshop Summary. American Journal of Respiratory and Critical Care Medicine, 163, 1256-1276. https://doi.org/10.1164/ajrccm.163.5.2101039

[46] Yohannes, A.M., Connolly, M.J. and Hanania, N.A. (2013) Ten Years of Tiotropium: Clinical Impact and Patient Perspectives. International Journal of Chronic Obstructive Pulmonary Disease, 8, 117-125. https://doi.org/10.2147/COPD.S28576

[47] Dahl, R., Chung, K.F., Buhl, R., Magnussen, H., Nonikov, V., Jack, D., Bleasdale, P., Owen, R., Higgins, M. and Kramer, B., INVOLVE (INdacaterol: Value in COPD: Longer Term Validation of Efficacy and Safety) Study Investigators (2010) Efficacy of a New Once-Daily Long-Acting Inhaled $\beta_{2}$-Agonist Indacaterol versus Twice-Daily Formoterol in COPD. Thorax, 65, 473-479.

https://doi.org/10.1136/thx.2009.125435

[48] Kornmann, O., Dahl, R., Centanni, S., Dogra, A., Owen, R., Lassen, C. and Kramer, B., INLIGHT-2 (Indacaterol Efficacy Evaluation Using 150- $\mu$ g Doses with COPD Patients) Study Investigators (2011) Once-Daily Indacaterol versus Twice-Daily Salmeterol for COPD: A Placebo-Controlled Comparison. European Respiratory Journal, 37, 273-279. https://doi.org/10.1183/09031936.00045810

[49] Donohue, J.F., Fogarty, C., Lötvall, J., Mahler, D.A., Worth, H., Yorgancioglu, A., Iqbal, A., Swales, J., Owen, R., Higgins, M. and Kramer, B., INHANCE Study Investigators (2010) Once-Daily Bronchodilators for Chronic Obstructive Pulmonary Disease: Indacaterol versus Tiotropium. American Journal of Respiratory and Critical Care Medicine, 182, 155-162. https://doi.org/10.1164/rccm.200910-1500OC

[50] Feldman, G., Siler, T., Prasad, N., Jack, D., Piggott, S., Owen, R., Higgins, M. and Kramer, B., INLIGHT 1 Study Group (2010) Efficacy and Safety of Indacaterol 150 Microg Once-Daily in COPD: A Double-Blind, Randomised, 12-Week Study. BMC Pulmonary Medicine, 10, Article No. 11. https://doi.org/10.1186/1471-2466-10-11

[51] Chapman, K.R., Rennard, S.I., Dogra, A., Owen, R., Lassen, C. and Kramer, B., INDORSE Study Investigators (2011) Long-Term Safety and Efficacy of Indacaterol, a Long-Acting $\beta_{2}$-Agonist, in Subjects with COPD: A Randomized, Placebo-Controlled Study. Chest, 140, 68-75. https://doi.org/10.1378/chest.10-1830

[52] Cazzola, M. and Molimard, M. (2010) The Scientific Rationale for Combining Long-Acting $\beta_{2}$-Agonists and Muscarinic Antagonists in COPD. Pulmonary Pharmacology and Therapeutics, 23, 257-267. https://doi.org/10.1016/j.pupt.2010.03.003

[53] Cazzola, M., Calzetta, L., Page, C.P., Rogliani, P., Facciolo, F., Gavaldà, A. and Matera, M.G. (2014) Pharmacological Characterization of the Interaction between Aclidinium Bromide and Formoterol Fumarate on Human Isolated Bronchi. European Journal of Pharmacology, 745, 135-143. https://doi.org/10.1016/j.ejphar.2014.10.025

[54] van Noord, J.A., Aumann, J.L., Janssens, E., Verhaert, J., Smeets, J.J., Mueller, A. and Cornelissen, P.J. (2006) Effects of Tiotropium with and without Formoterol on Airflow Obstruction and Resting Hyperinflation in Patients with COPD. Chest, 129, 509-517. https://doi.org/10.1378/chest.129.3.509

[55] Vogelmeier, C., Kardos, P., Harari, S., Gans, S.J., Stenglein, S. and Thirlwell, J. (2008) Formoterol Mono- and Combination Therapy with Tiotropium in Patients with COPD: A 6-Month Study. Respiratory Medicine, 102, 1511-1520. https://doi.org/10.1016/j.rmed.2008.07.020

[56] Tashkin, D.P., Pearle, J., Iezzoni, D. and Varghese, S.T. (2009) Formoterol and Tiotropium Compared with Tiotropium Alone for Treatment of COPD. COPD. Journal of Chronic Obstructive Pulmonary Disease, 6, 17-25. 
https://doi.org/10.1080/15412550902724073

[57] van Noord, J.A., Aumann, J.L., Janssens, E., Smeets, J.J., Zaagsma, J., Mueller, A. and Cornelissen, P.J. (2010) Combining Tiotropium and Salmeterol in COPD: Effects on Airflow Obstruction and Symptoms. Respiratory Medicine, 104, 995-1004. https://doi.org/10.1016/j.rmed.2010.02.017

[58] Brusasco, V. (2006) Reducing Cholinergic Constriction: The Major Reversible Mechanism in COPD. European Respiratory Review, 15, 32-36. https://doi.org/10.1183/09059180.00009902

[59] Buhl, R., Maltais, F., Abrahams, R., Bjermer, L., Derom, E., Ferguson, G., Fležar, M., Hébert, J., McGarvey, L., Pizzichini, E., Reid, J., Veale, A., Grönke, L., Hamilton, A., Korducki, L., Tetzlaff, K., Waitere-Wijker, S., Watz, H. and Bateman, E. (2015) Tiotropium and Olodaterol Fixed-Dose Combination versus Mono-Components in COPD (GOLD 2-4). European Respiratory Journal, 45, 969-979.

https://doi.org/10.1183/09031936.00136014

[60] Vogelmeier, C., Hederer, B., Glaab, T., Schmidt, H., Rutten-van Mölken, M.P., Beeh, K.M., Rabe, K.F. and Fabbri, L.M., POET-COPD Investigators (2011) Tiotropium versus Salmeterol for the Prevention of Exacerbations of COPD. The New England Journal of Medicine, 364, 1093-1103. https://doi.org/10.1056/NEJMoa1008378

[61] Rodrigo, G.J. and Neffen, H. (2012) Comparison of Indacaterol with Tiotropium or Twice-Daily Long-Acting $\beta$-Agonists for Stable COPD: A Systematic Review. Chest, 142, 1104-1110. https://doi.org/10.1378/chest.11-2252

[62] Cope, S., Donohue, J.F., Jansen, J.P., Kraemer, M., Capkun-Niggli, G., Baldwin, M., Buckley, F., Ellis, A. and Jones, P. (2013) Comparative Efficacy of Long-Acting Bronchodilators for COPD: A Network Meta-Analysis. Respiratory Research, 14, Article No. 100. https://doi.org/10.1186/1465-9921-14-100

[63] Dale, P.R., Cernecka, H., Schmidt, M., Dowling, M.R., Charlton, S.J., Pieper, M.P. and Michel, M.C. (2014) The Pharmacological Rationale for Combining Muscarinic Receptor Antagonists and $\beta$-Adrenoceptor Agonists in the Treatment of Airway and Bladder Disease. Current Opinion in Pharmacology, 16, 31-42. https://doi.org/10.1016/j.coph.2014.03.003

[64] Cohen, J.S., Miles, M.C., Donohue, J.F. and Ohar, J.A. (2016) Dual Therapy Strategies for COPD: The Scientific Rationale for LAMA + LABA. International Journal of Chronic Obstructive Pulmonary Disease, 11, 785-797.

https://doi.org/10.2147/COPD.S54513

[65] López-Campos, J.L. (2013) $\mathrm{M}_{2}-\beta_{2}$ Interaction: A Basis for Combined Bronchodilator Treatment. Archivos de Bronconeumología, 49, 279-281. (Article in English, Spanish) https://doi.org/10.1016/j.arbr.2012.10.006

[66] Tashkin, D.P. and Ferguson, G.T. (2013) Combination Bronchodilator Therapy in the Management of Chronic Obstructive Pulmonary Disease. Respiratory Research, 14, Article No. 49. https://doi.org/10.1186/1465-9921-14-49

[67] Matera, M.G., Rogliani, P., Calzetta, L. and Cazzola, M. (2016) Safety Considerations with Dual Bronchodilator Therapy in COPD: An Update. Drug Safety, 39, 501-508. https://doi.org/10.1007/s40264-016-0402-4

[68] López-Campos, J.L., Abad-Arranz, M. and Calero-Acuña, C. (2015) Double or Dual Bronchodilation: Defining the Correct Term. Archivos de Bronconeumología, 51, 661. (Article in English, Spanish) https://doi.org/10.1016/j.arbr.2015.10.006

[69] Ficker, J.H., Rabe, K.F. and Welte, T. (2017) Role of Dual Bronchodilators in COPD: A Review of the Current Evidence for Indacaterol/Glycopyrronium. Pul- 
monary Pharmacology and Therapeutics, 45, 19-33. https://doi.org/10.1016/j.pupt.2017.04.002

[70] Frampton, J.E. (2014) QVA149 (Indacaterol/Glycopyrronium Fixed-Dose Combination): A Review of Its Use in Patients with Chronic Obstructive Pulmonary Disease. Drugs, 74, 465-488. https://doi.org/10.1007/s40265-014-0194-8

[71] Banerji, D., Fogel, R. and Patalano, F. (2018) Indacaterol/Glycopyrronium: A Dual Bronchodilator for COPD. Drug Discovery Today, 23, 196-203. https://doi.org/10.1016/j.drudis.2017.10.015

[72] Rodrigo, G.J., Price, D., Anzueto, A., Singh, D., Altman, P., Bader, G., Patalano, F., Fogel, R. and Kostikas, K. (2017) LABA/LAMA Combinations versus LAMA Monotherapy or LABA/ICS in COPD: A Systematic Review and Meta-Analysis. International Journal of Chronic Obstructive Pulmonary Disease, 12, 907-922. https://doi.org/10.2147/COPD.S130482

[73] Takegahara, K., Usuda, J., Inoue, T., Ibi, T. and Sato, A. (2017) Preoperative Management Using Inhalation Therapy for Pulmonary Complications in Lung Cancer Patients with Chronic Obstructive Pulmonary Disease. General Thoracic and Cardiovascular Surgery, 65, 388-391. https://doi.org/10.1007/s11748-017-0761-5

[74] Makino, T., Otsuka, H., Hata, Y., Koezuka, S., Azuma, Y., Isobe, K., Sugino, K., Ebihara, S., Homma, S. and Iyoda, A. (2018) Long-Acting Muscarinic Antagonist and Long-Acting $\beta_{2}$-Agonist Therapy to Optimize Chronic Obstructive Pulmonary Disease Prior to Lung Cancer Surgery. Molecular and Clinical Oncology, 8, 647-652. https://doi.org/10.3892/mco.2018.1595

[75] Price, D., Yawn, B., Brusselle, G. and Rossi, A. (2013) Risk-to-Benefit Ratio of Inhaled Corticosteroids in Patients with COPD. Primary Care Respiratory Journal, 22, 92-100. https://doi.org/10.4104/pcrj.2012.00092

[76] Suissa, S., McGhan, R., Niewoehner, D. and Make, B. (2007) Inhaled Corticosteroids in Chronic Obstructive Pulmonary Disease. Proceedings of the American Thoracic Society, 4, 535-542. https://doi.org/10.1513/pats.200701-024FM

[77] Jones, P.W. and Agusti, A.G. (2006) Outcomes and Markers in the Assessment of Chronic Obstructive Pulmonary Disease. European Respiratory Journal, 27, 822-832. https://doi.org/10.1183/09031936.06.00145104

[78] Jones, P.W. (2001) Health Status Measurement in Chronic Obstructive Pulmonary Disease. Thorax, 56, 880-887. https://doi.org/10.1136/thorax.56.11.880

[79] Lavorini, F. (2005) Quantifying Bronchodilator Responses in Chronic Obstructive Pulmonary Disease Trials. British Journal of Clinical Pharmacology, 59, 385-386. https://doi.org/10.1111/j.1365-2125.2005.02400.x

[80] Chronic Obstructive Pulmonary Disease: Developing Drugs for Treatment; Draft Guidance for Industry; Availability.

https://www.federalregister.gov/documents/2016/05/20/2016-11855/chronic-obstru ctive-pulmonary-disease-developing-drugs-for-treatment-draft-guidance-for-indust ry

[81] Mahler, D.A., Ward, J., Fierro-Carrion, G., Waterman, L.A., Lentine, T.F., Mejia-Alfaro, R. and Baird, J.C. (2004) Development of Self-Administered Versions of Modified Baseline and Transition Dyspnea Indexes in COPD. COPD: Journal of Chronic Obstructive Pulmonary Disease, 1, 165-172. https://doi.org/10.1081/COPD-120030829

[82] Jones, P.W. (1991) Quality of Life Measurement for Patients with Diseases of the Airways. Thorax, 46, 676-682. https://doi.org/10.1136/thx.46.9.676 